\title{
방글라데시의 경제현황 및 빈곤경감전략(PRSP)
}

이 정 욱 / KOICA 방글라데시 사무소장

I. 최근 경제현황 및 빈곤문제

1. 최근 경제현황

2. 빈곤 문제

II. 방글라데시 빈곤경감전략 보고서(PRSP)

1. 개 요 84

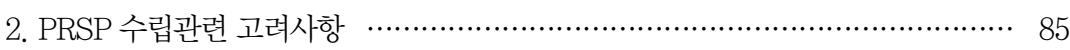

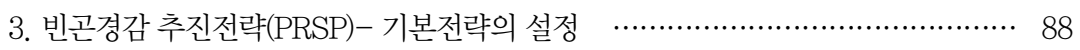
전략 $1-$ 빈곤층을 위한 거시경제 환경 조성

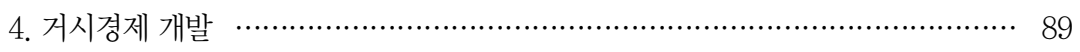

5. 무역활성화 및 해외근로자 송금 확대 ………………………………...... 92

전략 2- 빈곤층의 자립을 위한 분야별 경제성장 촉진

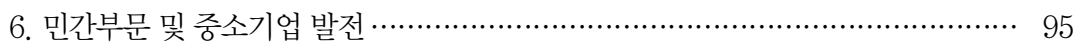

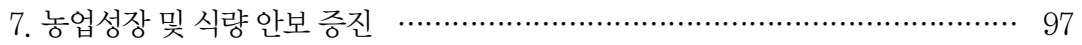

8. 소액 대출(micro-credit) 활성화 …………………………………....... 98

9. 인프라 개발 및 개선 ………………………………………………... 98

10. 빈곤경감을 위한 관광사업 개발 …………………............................ 100

11. 정보통신 및 생명공학 지원 ㄱ..……………………………………..... 101

전략 3- 효과적인 사회안전 대책 프로그램

12. 빈곤경감을 위한 재해 관리 및 안전 대책 …………................................ 102

전략 4- 인적 자원 개발 (Human Resources Development)

13. 교육 분야 ……………………………………………………..... 103

14. 보건위생 분야 ………………………………….......................... 107

보조전략- 비주류의 사회참여 및 좋은 통치(Good Governance)

16. 여성권리 및 여성 참여 확대 ………………………........................... 110

17. 좋은 통치(Good Governance) ……………………………………..... 111

III. PRSP 평가 및 향후 전망

1. 향후 경제전망 및 PRSP 추진 ……………………….......................... 113

2. 전략의 효율성 평가 …………………………………………........... 114

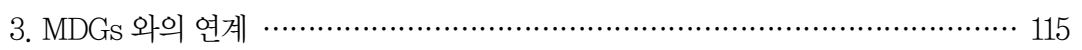




\section{I. 최근 경제현황 및 빈곤문제}

\section{1. 최근 경제현황}

\section{가. 거시경제 현황}

방글라데시 경제는 FY '04년 5.3\%, FY '03년 에 $5.2 \%$ 에 이어 $\mathrm{FY}{ }^{\prime} 05$ 년에도 비교적 고성장인 $5.4 \%$ 성장의 실질 $\mathrm{GDP}$ 성장률을 시현하였다. 경 제성장은 '04년 7월 발생한 심각한 홍수피해와 '05년 이후 지속적으로 상승한 국제유가 및 이에 따른 물가상승 압력, '04년말 다자간 섬유협정 (MFA) 종료에 따른 섬유수출 경쟁력 악화 등 어려 운 경제상황에서 이룩한 것으로 특별한 의미를 지 닌다. 동 기간중 제조업과 건설, 서비스 부문에서 지속적인 국내외시장 확대가 이루어졌으며, 이는 농업부문에서의 부진한 성과를 상쇄시키며 안정적

〈 방글라데시 경제성장률 및 1인당 GDP 추이〉

\begin{tabular}{c|r|r|r|r|r|r|r}
\hline 구 분 & $\prime 99$ & $\prime 00$ & $\prime 01$ & $\prime 02$ & $' 03$ & $' 04$ & $' 05$ \\
\hline 성장률(\%) & 4.9 & 5.9 & 5.3 & 4.4 & 5.3 & 6.3 & 5.4 \\
\hline 1인당 GDP & 354.1 & 367.3 & 371.1 & 372.0 & 389.0 & 418.0 & 445.0 \\
\hline 자료: World Bank, Bangladesh Development Series, 2005
\end{tabular}

〈방글라데시 거시경제 지표 1984 2004 〉

\begin{tabular}{|c|c|c|c|c|}
\hline 분 & 1984 & 1994 & 2003 & 2004 \\
\hline GDP(10억불) & 19.7 & 33.8 & 51.9 & 56.6 \\
\hline 총자본율/GDP대비 & 15.9 & 18.4 & 23.4 & 24.0 \\
\hline 수출액/GDP대비 & 3.3 & 9.0 & 14.2 & 15.5 \\
\hline 국내저축/GDP대비 & 6.2 & 13.5 & 18.6 & 19.5 \\
\hline 총 저축/GDP대비 & 16.2 & 18.8 & 24.9 & 25.4 \\
\hline 재정수지/GDP대비 & -1.1 & -0.3 & 0.1 & 0.3 \\
\hline 외채이자 지급/GDP대비 & 0.6 & 0.5 & 0.3 & 0.3 \\
\hline 총 부채/GDP대비 & 28.7 & 46.3 & 36.2 & 35.4 \\
\hline 부채비율/수출액 대비 & 17.7 & 12.9 & 6.4 & 8.0 \\
\hline 외채/GDP대비 &.. & .. & 24.7 & .. \\
\hline 외채/출액 대비 & .. & .. & 122.0 &.. \\
\hline
\end{tabular}

성장세를 유지하였다.

$\mathrm{FY}$ ' 05 년의 $\mathrm{GDP}$ 성장은 개인소비와 수출의 확 대, 500만 이상으로 추정되는 해외근로자의 송금, 정부와 선진원조기관의 홍수피해 구호기금방출, 외국인 직접투자를 비롯한 개인투자의 급격한 성 장에 의해 이루어졌다. 국내저축율은 FY' 04 년 $\mathrm{GDP}$ 의 $19.5 \%$ 에서 FY '05년에는 $20.2 \%$ 로 증가 하였으며 개인투자 역시 FY '04년 GDP의 $17.8 \%$ 이였던 것이 $\mathrm{FY}{ }^{\prime} 05$ 년 $18.5 \%$ 로 증가, 경제성장이 국내소비와 저축, 섬유업 수출에 의해 견인되며 성 장내용도 견실해진 것으로 평가된다. 특히 투자와 저축비율의 증가는 미래성장을 확보하는데 긍정적 인 요소로 주목된다.

〈방글라데시 주요 경제지표 2005 〉

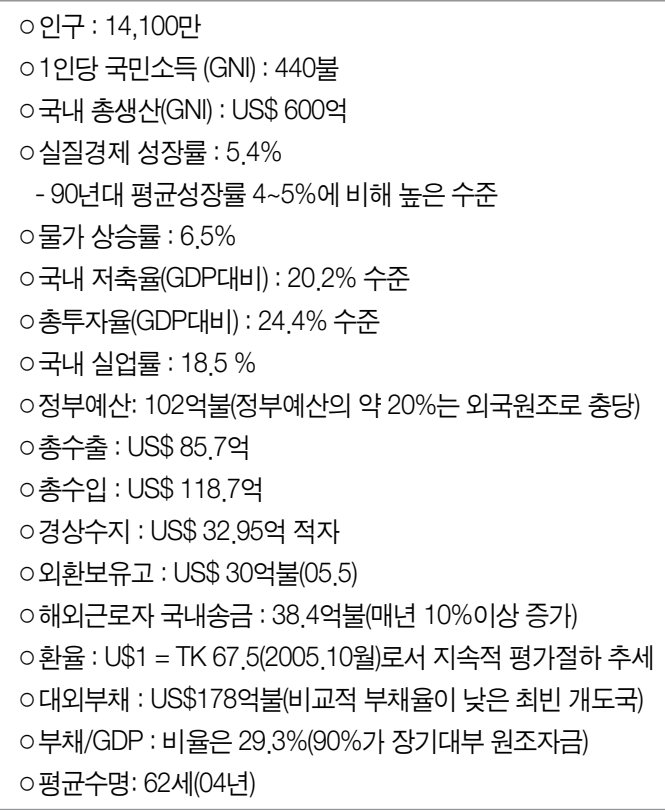

\section{나. 재정 건전성 및 세수 개선}

방글라데시의 재정적자 규모가 $\mathrm{FY}$ '05년도의 
경우, $\mathrm{GDP}$ 대비 3.5\% 수준으로 $\mathrm{FY}$ '04년 3.2\%, $\mathrm{FY}{ }^{\prime}$ O3년 3.4\%와 비교시 약간 증가한 것으로 추 정된다. 이는 정부의 홍수피해 예산집행과 저조한 세수실적 때문으로 파악된다. 방글라데시는 만성 적 세입부족으로 세수원확보에 노력하고 있으나 토착화된 세무관련 비리로 징수율은 $30 \%$ 에 불과 하며, 매년 정부는 세출예산의 약 $20 \%$ 를 외국 원 조자금으로 충당하고 있다.

방글라데시는 세입예산이 GDP의 $10 \%$ 도 안될 정도로 매우 낮고 136 백만 인구중에서 납세자는 아주 소수이다. 이는 방글라데시 국세청(NBR)에 대해 심각한 도전과제를 제시한다. 허술한 납세제 도는 부정부패의 커다란 동기를 부여해주는 기초 가 된다. 이는 정부에 개발사업과 공공서비스 지 출에 충분한 재원을 공급하지 않으며, Rentseeking(정부규제에 따른 독점기회를 확보하기 위해 뇌물제공 및 로비하는 현상) 기회를 만들면 서 공공서비스의 집행과 산업인프라의 구축을 방 해한다.

정부는 재정적자폭을 $\mathrm{GDP}$ 대비 $0.2 \%$ 이내로 줄 이기 위해 국세청(NBR) 및 조세행정 개선을 주요 PRSP 과제로 상정하고 있으나, 구조적 부패를 뿌 리 뽑는데는 상당시일이 필요할 것으로 보인다.

한편, 정부예산(약 102 억불)의 $48 \%$ 를 차지하는 개발사업예산(ADP) 집행율은 계획대비 $16.8 \%$ 나 낮은 수준으로 나타났는데, 이는 선진국들이 원조 예산의 집행과 관련하여 절차의 투명성(조달규정 개정)을 요구하면서 국내관련법 정비가 이에 따르 지 못하고 있기 때문으로 보인다.

\section{다. 외채 및 인플레이션}

방글라데시의 부채규모는 GDP의 $30 \%$ 수준으 로 대부분이 세계은행 등 원조자금의 저리차관으 로 구성되어 있으며, 타 저소득국가에 비교시 동 비율은 낮은 편으로 평가할 수 있다. 다만, 방글라 데시의 외환보유(30억불) 및 수출규모(85억불)를 고려시, 중장기적으로 동 부채규모는 유동성 위험 을 유발할 수 있다. 따라서 중장기 유동성 안정화 를 위해서는 경제규모의 확대와 더불어 경상수지 개선 노력이 뒤따라야할 것이다.

방글라데시의 경제관련 지표 중 우려되고 있는 것이 물가지수로 2005 년의 경우 인플레율이 $7.9 \%$ 를 보였다. 물가상승율이 7.5\%를 넘은 것은 1999 년 6월이후 처음인데, 2004년 5.5\%, 2005년 초 $7.3 \%$ 등 인플레 압력이 갈수록 높아지고 있음을 알 수 있다.

최근의 높은 인플레이션은 과거 홍수로 인한 농 업부분에서의 일시적 물가상승과는 다르게 전산업 부분에 영향을 주고 있으며, 특히 석유관련 제품과 아만(Aman) 등 빈민층이 이용하는 수입쌀 가격의 급등을 불러와 서민들의 생활고를 자극하였다. 인 플레가 진정되지 않을 경우 서민들의 생활고는 물 론, 이자율의 상승으로 기업 환경이 더욱 악화될 것으로 염려된다.

\section{라. 향후 경제성장 과제}

방글라데시는 지속적 경제성장을 유지하기 위 한 다음과 같은 몇 가지 문제에 직면하고 있다. 즉, 국제유가의 급격한 상승과 수출주력부문인 섬유산 
업이 다자간섬유협정(MFA) 폐지(쿼터제 폐지 및 자유경쟁에 근거한 수출시장 확보)에 따라 해외시 장 확보에 어려움이 예상되며, 2007년 1월 총선을 대비한 국내정치 혼란 및 정치폭력(이슬람 원리주 의자에 의한 폭탄테러 빈발), 무능하고 부패한 정 부행정 등이다.

국제시장에서 급등하고 있는 원유가는 방글라데 시의 성장잠재력을 해치고, 거시경제의 안정성과 외환사정 악화 등 방글라데시와 같은 저소득국 국 가경제에 심각한 위험을 불러일으킨다. 치솟은 국 제유가는 인플레이션을 유발하고 외환상환 압력을 가중시키며 달러화 유동성을 악화시켜 다카화 평 가절하를 유발하고 있다. 다카화는 05년1월 이후 1 년간 달러화 대비 $15 \%$ 이상 절하되며 수입품 물가 상승 압력이 거세지고 있다. 정부는 국내 물가안정 을 위하여 원유가 인상을 최대한 억제하고 있으나 이는 방글라데시 국영석유회사(BPC)의 부실을 촉 진하고 공공채무를 증가시키는 등 국가재정에도 영향을 미치고 있다. 지난 12 개월간 국내유가는 국 제원유가 상승분(86\%)에 비해 매우 적게(30\%) 상 승했는데, 이로 인한 FY06년 국가재정 손실이 300 억TK(4.5억달러)에 이를 것으로 보인다.

섬유산업은 방글라데시 총 수출의 $70 \%$ 를 차지 하는 국가 주력 수출산업으로, 다자간 섬유협정 (MFA) 종료에 따른 방글라데시 섬유업체들의 수 출경쟁력 확보 여부가 과제로 남아 있다. 2005.1 $\mathrm{MFA}$ 폐지이후 몇 달간 실적을 보면 대미 직물수 출이 급격히 증가, 2005년 상반기중 전년 동기대 비 $21.5 \%$ 성장율을 보이고 있으며 반면, 유럽연합
(EU)에 대한 수출은 상당폭 감소하였다. 전체적으 로 니트웨어 수출이 강세를 보이는 등 섬유업 전체 로 성장세를 유지하고 있지만 공급업자들의 경쟁 으로 가격은 하락세를 보이고 있다. 전문가들은 $\mathrm{MFA}$ 종료이후 방글라데시 섬유업이 지속발전을 유지하기 위해서는 가격 경쟁력 확보, 리드 타임 (기획에서 제품화까지 소요시간) 축소, 노동환경 개선 등 3 가지 과제를 풀어야 할 것으로 보고 있 다. 즉, 우수한 기술력과 더 많은 자본을 가진 섬유 업체가 살아남을 수 있도록 국내시장을 정비하고, 경쟁국가들보다 1 개월 이상 긴 리드타임을 줄이는 노력(수출관련산업의 수직 계열화로 리드타임과 제조원가 절감), 선진국 대부분이 섬유제품 수입시 여성 및 미성년 고용금지 등 국제노동협약 준수여 부를 검증하는 점을 고려한 노동환경 개선이 요구 되고 있다.

그 밖에도 경제발전의 병목 요인들, 예컨데 인 프라(에너지, 항만, 도로 등) 개선 및 과학기술과 기초 기술을 향상시키고 공공과 민간부문의 협력 관계 증진, $\mathrm{SME}$ (중소기업) 부문의 육성 등이 주요 한 과제로 거론되어야 할 것이다.

\section{2. 빈곤 문제}

\section{가. 빈곤경감 노력과 성과들}

1971년 독립한 방글라데시는 극도로 빈약한 국 가재정, 정치불안 및 폭력, 공공부문 비효율, 홍수 등 만성적인 자연재해와 이러한 요인들 로 인하여 고착된 부정적인 국가 이미지들에 맞서 상당히 긍 
정적인 발전을 성취했다. 방글라데시는 저소득 국 가중 1990 년 초반 이후 매년 긍정적인 1 인당 성장 을 지속하는 몇몇 나라 중 하나이다.

빈곤상황의 개선을 보면, 1990 년 $60 \%$ 이였던 빈 곤율(poverty rate)이 2000년 50\%로 감소되었고, 1990년 이후에는 빈곤율이 매년 $1 \%$ 씩 감소하고 있다. 유엔은 저소득국(Low-income countries) 중 최근 5 년간 경제성장율이 평균 $5 \%$ 이상을 유지 하고 있는 몇몇 소수의 나라중 하나로 방글라데시 를 주목하고 있다.

〈 방글라데시 빈곤 추이비교 1992 2000 〉

\begin{tabular}{|c|c|c|c|c|c|c|}
\hline \multirow{2}{*}{ 구 분 } & \multicolumn{3}{|c|}{ 상위 빈곤선(소득: \$1/일) } & \multicolumn{3}{|c|}{ 하위빈곤선(소득 $\$ 1$ 미만/일) } \\
\hline & 1992 92 & 1995 96 & 2000 & 1991 92 & |1995 96 & 2000 \\
\hline \multicolumn{7}{|l|}{ 빈곤인구 } \\
\hline 국가 & 58.8 & 51.0 & 49.8 & 42.7 & 4.4 & 33.7 \\
\hline 도시 & 44.9 & 29.4 & 36.6 & 23.3 & 13.7 & 19.1 \\
\hline 농촌 & 61.2 & 55.2 & 53.0 & 46.0 & 38.5 & 37.4 \\
\hline \multicolumn{7}{|l|}{ 빈곤 GAP } \\
\hline 국가 & 17.2 & 13.3 & 12.9 & 10.7 & 7.6 & 7.3 \\
\hline 도시 & 12 & 7.2 & 9.5 & 4.9 & 2.6 & 3.8 \\
\hline 농촌 & 18.1 & 14.5 & 13.9 & 11.7 & 8.6 & 8.2 \\
\hline
\end{tabular}

한편, 방글라데시 사회개발 지표(Social Development Index)의 개선 도 괄목한 변화를 보 이고 있다. 예컨대 초등학교 남녀 취학률은 $100 \%$ 에 근접하고 있으며 중학교 취학률도 독립이후
2 배나 향상되었다. 또한 방글라데시는 이미 중학 교와 초등학교 남여입학 성균형(gender parity)에 있어서 새천년 개발목표(MDGs)를 충족시켰다. 1971년 방글라데시 독립이후 아동사망률이 반감 (牛減)했으며 평균 기대수명은 15 년(46세 $\rightarrow 61$ 세) 이상 증가하였다. 유아와 아동 사망률은 1972년 각각 천명당 140 명과 95 명 수준이었으나 2000년 에는 60 명과 30 명으로 개발도 상국중 가장 빠른 감소치를 보이고 있다. 이런 추세가 계속 진행된다 면 방글라데시와 몰디브는 남아시아 국가 가운데 유아, 아동 사망률 감소에 있어 그들의 MDGs를 달성하는 유일한 나라들이 될 것이라고 유엔보고 서는 지적하였다. 가족계획 성과에 있어서도 가임 여성 1인당 출생아가 1975년 6.3명에서 3.3명으로 감소함에 따라 방글라데시의 고질병중 하나였던 인구 성장률을 1990 년 중반까지 년 $1.5 \%$ 로 감소시 키는 결과를 낳았다.

비록 방글라데시가 종종 빈곤의 악순환에 갇혀 있는 불행한 나라로 여겨지지만 성장률과 실제 사 회개발의 성과면에서 적지 않은 열매를 거둔 것으 로 보인다. 실제로 방글라데시는 동 지역 여타 저 소득국가와 비교시 사회개발 측면에서 빠르게 발 전하고 있다.

〈서남아시아 국가별 보건지표 개선 비교 1990 2000〉

\begin{tabular}{|c|c|c|c|c|c|c|}
\hline 국가명 & $\begin{array}{l}\text { 아동영양결핍 } \\
\text { 감소율(\%) }\end{array}$ & $\begin{array}{c}\text { 산모 사망률 (만명 } \\
\text { 당)출생율(\%) }\end{array}$ & 출생율(\%) & $\begin{array}{l}\text { 초등교육 } \\
\text { 진학률(\%) }\end{array}$ & $\begin{array}{c}\text { 아동예방주사 } \\
\text { 접종률(\%) }\end{array}$ & 여성취업률(\%) \\
\hline 방글라데시 & -52 & 380 & -29 & 59 & 85 & 68 \\
\hline 인도 & -29 & 540 & -24 & 4 & 70 & 45 \\
\hline 파키스탄 & * & 500 & -22 & * & 67 & 39 \\
\hline 네팔 & -29 & 740 & -23 & 19 & 78 & 58 \\
\hline
\end{tabular}

자료: World Bank, World Development Indicators 2005 
〈방글라데시 사회개발 지표 1970 2000〉

\begin{tabular}{|c|c|c|c|c|c|}
\hline \multirow{2}{*}{ 구 분 } & \multicolumn{3}{|c|}{ 년도별 증감 현황 } & \multicolumn{2}{|c|}{ 지역/국가별 비교 } \\
\hline & $1970-75$ & $1980-85$ & 1994-00 & 남아시아 & 저소득국(LIC) \\
\hline \multicolumn{6}{|l|}{ 인구총 } \\
\hline 인구(백만) & 75.6 & 97.1 & 131.1 & $1,335.1$ & 2.459 .8 \\
\hline 인구성장율(\%) & 2.6 & 2.6 & 1.7 & 1.9 & 2.0 \\
\hline 도시인구(\%) & 9.8 & 17.0 & 24.5 & 28.4 & 31.9 \\
\hline 출산율(가임 여성1인당) & 6.6 & 5.3 & 3.1 & 3.3 & 3.6 \\
\hline \multicolumn{6}{|l|}{ 빈곤층(\%) } \\
\hline 국가 평균 & .. & .. & 35.6 &.. &.. \\
\hline 도시 &.. &.. & 14.3 &.. &.. \\
\hline 농촌 &. & .. & 39.8 &.. &.. \\
\hline \multicolumn{6}{|l|}{ 소득 } \\
\hline 1인당 GNI(US\$) & 200 & 200 & 370 & 440 & 410 \\
\hline 소비자 물가지수(1995=100) &. & .. & 129 & 142 & 140 \\
\hline 식량물가 지수(1995=100) &. & 52 & 117 & & .. \\
\hline \multicolumn{6}{|l|}{ 소득/소비 지출(\%) } \\
\hline Gini 계수 & .. &.. & 33.6 &.. &.. \\
\hline 상위 25\% 소득/소비지출(\%) &.. &.. & 8.7 &.. &.. \\
\hline 하위 25\% 소득/소비지출(\% &.. & .. & 42.8 &.. &.. \\
\hline \multicolumn{6}{|l|}{ 보건,교육분야 공공지출 } \\
\hline 보건예산(\%, GDP) &.. & .. & 1.7 & 0.9 & 1.2 \\
\hline 교육예산(\%, GDP) & 0.8 & 1.4 & 2.4 & 3.0 & 3.4 \\
\hline 사회복지, 안전예산(\%, GDP) & .. & .. & .. & .. & .. \\
\hline \multicolumn{6}{|l|}{ 초등학교 입학율 } \\
\hline 전체 & 50 & 56 & 104 & .. &. \\
\hline 남자 & 66 & 65 & 106 &.. & .. \\
\hline 여자 & 33 & 47 & 102 &.. &. \\
\hline \multicolumn{6}{|l|}{ 안전식수 이용율(\%) } \\
\hline 전체(인구) & .. & .. & 97 & 87 & 76 \\
\hline 도시 &.. &.. & 99 & 92 & 88 \\
\hline 농촌 & .. &.. & 97 & 85 & 70 \\
\hline \multicolumn{6}{|l|}{ 예방주사 접종율(\%, 1 세미만) } \\
\hline 홍역 &. & 1 & 71 & 53 & 57 \\
\hline DPT & .. & 2 & 72 & 57 & 57 \\
\hline 유아 영양실조율(\%, 5세미만) & .. & 68 & 61 & 49 & .. \\
\hline \multicolumn{6}{|l|}{ 기대수명 } \\
\hline 전체 & 46 & 52 & 61 & 62 & 59 \\
\hline 남자 & 47 & 52 & 61 & 62 & 58 \\
\hline 여자 & 45 & 51 & 62 & 63 & 60 \\
\hline \multicolumn{6}{|l|}{ 사망율 } \\
\hline 영아사망율(천명당) & 138 & 114 & 60 & 73 & 76 \\
\hline 5세미만아 사망율(천명당) & 239 & 173 & 83 & 96 & 115 \\
\hline \multicolumn{6}{|l|}{ 성인(15-59) } \\
\hline 남자(천명당) & 473 & 383 & 278 & 227 & 294 \\
\hline 여자(천명당) & 486 & 388 & 272 & 212 & 261 \\
\hline 모성사망율(십만명당) & .. & .. & 600 &.. & .. \\
\hline 안전출산율(\%) &.. & 5 & 14 &.. & .. \\
\hline
\end{tabular}




\section{나. 현존하는 개발과제들}

빈곤개선의 성과와 지속적인 발전에도 불구하고 방글라데시는 개발 과제가 산적해 있다. 우선, 전체 인구의 절반에 가까운 6,500 만명이 아직도 빈곤선 (poverty line) 아래에 있으며 하루 $\$ 2$ 미만의 소득 을 얻고 있는 빈곤인구가 전체 인구의 $84 \%$ 를 점하 고 있다. 1 인당 $\mathrm{GDP}$ 수준은 유엔의 조사대상국 201 국중 174 위에 머물러 있으며 문맹률(15세이상) 은 $60 \%$ 에 육박하고 있다. 비록 방글라데시가 남아 시아 지역에서 아동 영양 결핍율과 산모사망률이 가장 낮은 수준이나 남아시아 지역이 사하라 남부 아프리카 지역을 제외하고 개도국 가운데 동 지표 가 가장 열악한 지역임을 감안할 필요가 있다. 소득 의 지역편차 및 양극화 현상도 심각하다. 1-3세 아 동의 반 이상이 저 체중아이며, 성인 여성의 $40 \%$ 이 상이 영양부족(실조포함) 상태에 있기도 하다.

한편 신생아 출산시 전문적인 의료인의 도움을 받는 비율은 저소득층의 경우 $1.5 \%$ 미만이지만 고 소득층의 경우 $22 \%$ 로 그 격차가 심각하다. 교육의 기회가 많아졌음에도 불구하고 내용이 부실하고 중도 탈락율이 높아 1학년에서 12 학년까지 마치는 학생이 $10 \%$ 미만일 정도로 매우 미미하다.

무엇보다 방글라데시는 거버넌스 측면에서 발 전을 저해하는 지속적이고 심각한 문제에 직면하 고 있다. 특별히 법질서의 집행이 권력과 유관하여 자의적이며 공공조직은 각종 이권과 결탁하여 비 리를 양산하는 원인으로 지목된다. 이 나라에서 공 공서비스는 뇌물없이는 적기 진행이 불가능할 정 도이며 서비스 공급과 수요자 모두 뇌물을 주고 받
는데 익숙하다. 국제투명성 기구(ITO) 조사에 따 르면 방글라데시는 5 년 연속 세계 제 1 의 부패국가 로 지목되었으며 당분간 이는 개선의 전망이 없어 보인다. 세계은행의 2002 년도 조사에 따르면 방글 라데시는 부패, 법질서 유지 측면에서 1990년 조 사보다 후퇴하였으며 조사대상국 209국 가운데 최악의 수준을 기록하였다.

부패하고 무능한 정부는 방글라데시의 국가 이 미지에 악영항을 미쳐 장기간 해외자본 유입에 심 각한 지장을 초래하였다. 방글라데시 정부도 최근 선진 공여국의 도움으로 거버넌스 문제를 해결하 기 위한 개혁 프로그램을 추진하고 있으며, 주요 대상은 공공 행정, 조세운영, 조달, 회계제도와 같 은 공공부분 효율성 향상 및 부패방지에 있으며 거 버넌스 달성을 위하여 최근 부패 방지위원회(ACC) 를 설치하였다.

\section{다. 방글라데시내 주요 빈곤 결정요소 및 대응 방안}

전문가들은 방글라데시내 주요 빈곤 결정 요소 를 10 가지 정도로 분석하였다. 주요 요인은 아래와 같다.

1) 전기

전기 연결이 되지 않는 가정이 전기 연결이 된 가정보다 더 가난 해 질 가능성이 높다.

\section{2) 여성보조금}

여성에게 부여하는 보조금 지원 프로그램은 빈 
곤 삭감에 중요한 역할을 하는 것으로 나타났다.

\section{3) 가장의 문자해독률}

문자해독률과 빈곤은 반 대칭 상관관계로, 문자 해독률이 높은 국민일수록 빈곤에서 멀어지는 것 을 목격할 수 있다.

\section{4) 기술 취득률}

기술취득및 기술력 향상 역시 빈곤 에서 벗어나 는데 유용한 요소로 나타났다.

\section{5) 토지소유}

경작할 수 있는 토지가 있는 것은 방글라데시에 서 빈곤 삭감에 매우 중요하다.

\section{6) 가족 구성원 수}

가족 구성원의 수가 높을수록 더욱 빈곤한 것으 로 나타났다. 효과적인 인구성장률 감소 정책이 필 요하다.

한편, 방글라데시내 빈곤에 효과적으로 대응하 는 방법에는 크게 4 가지가 있다.

\section{(1) 노동력 활성화}

빈곤층의 대부분에게는 노동이 가장 주된 자산 이자 수입원이라 할 수 있다. 빈곤층이 일할 수 있 는 환경을 조성하는 것과 일자리의 수를 증가시키 는 것이 중요하며, 농업 과 비농업분야에서의 노동 생산성의 증가가 중요한 과제로 떠오르고 있다.

(2) 기술과 교육
기술과 교육에 대한 무관심이 빈곤층 노동자의 경제활동 참여 범위를 축소하고 있으며, 직업선택 권도 좁아지게 하고 있다. 기술 훈련과 적절한 교 육환경 조성이 무엇보다 중요한 시점에 있다.

(3) 기초 인프라

전력, 도로 등 기초 인프라는 빈곤계층의 수입 과 빈곤 삭감에 매우 중 요한 역할을 하고 있다. 교 육 시설의 부족, 전기 연결의 실패가 빈 곤 가능성 을 더욱 높여주는 것으로 연구되었다.

(4) 공공 서비스 및 시장이용 확대

공공 서비스 제공 및 시장이용의 부족은 빈곤상 황을 더욱 악화시키는 요소들이다. 극 빈곤층에게 도 공공서비스가 도달할 수 있도록 공공서비스 제 공 확산 및 수혜층 확대, 빈곤층의 시장(market) 접근, 이용율 향상 등이 불평등 및 빈곤의 적절한 대응방안으로 떠오르고 있다.

\section{II. 방글라데시 빈곤경감전략(PRSP) 보고서}

\section{1. 개 요}

방글라데시 정부는 1971 독립이후 자국의 중장 기 경제개발 마스터 플랜으로 5 개년 경제개발계획 을 수립하여 왔으며, 지난 아와미 정권 (Awami League) 시절까지 제5차 경제개발계획('97.7.1 '02.6.30)을 수립하였다. 그러나 2001.10월 출범 한 현 $\mathrm{BNP}$ 정부는 제6차 경제개발계획을 수립하 지 않았으며, 대신 빈곤완화전략 보고서의 초안으 
로서 ‘잠정 빈곤완화전략' (I’PRSP: Interim Poverty Reduction Strategy Paper)를 작성하여 왔는데, 동 보고서에 정부의 빈곤완화 및 사회개발 을 위한 중기 계획을 열거하고 있다. 방글라데시 정부는 정식 빈곤경감보고서 마련을 위하여 2003.4 재무부내에 전담팀을 발족시켰으며 여기 에는 재무관료뿐 아니라, 19 개 부처의 관계자와 세 계은행등 원조기관, 학계, $\mathrm{NGO}$ 및 시민단체 등이 망라되었다.

2005년 10월 방글라데시 정부는 빈곤경감 가속 화를 위한 방글라데시국가전략 (원제:Unlocking the Poverty: National Strategy for Accelerated Poverty Reduction)을 발표하였으며 그해 11월 수 도 다카에서 빈곤경감전략 집행을 위한 국제회의 를 개최, 동 전략에 대한 타당성 검증, 국제사회의 지지와 동의를 구하였다. 원조기관들은 동 전략의 수립과 진행 및 평가과정에서의 적극적인 지원과 방글라데시 정부의 자립역량 및 자율성을 존중하 고 높이 평가하였다.

동 PRSP는 방글라데시 정부가 2015년까지의 $\mathrm{MDGs}$ 과제 달성을 감안하며 자국 상황에 따라 장 기적 개발전략을 구상한 것으로, 3년('06 '08)단 위의 단기 운영계획(rolling plan)을 포함하고 있 다. 한편 서방의 원조기관과 방글라데시 정부는 $\mathrm{PRSP}$ 의 이행상황을 점검하기위해 매년 2차례 집 행 및 평가회의를 개최하기로 합의하였다

$\mathrm{PRSP}$ 는 총 5 장으로 구성되어 있어 있다. 1장은 방글라데시의 전반적인 빈곤 현황에 관한 자료로 방글라데시의 주요 빈곤 경향, 주요 빈곤 요소, 빈
곤 대응 방안과 함께 방글라데시의 빈곤 현황을 수 치로 나타내어 대략적인 방글라데시 빈곤상황을 알 수 있다. 2장은 PRSP 전략 수립시 고려해야 할 주요 현안에 관한 내용으로 17 개로 분류하여 설명 하고 있다. 3 장은 PRSP 개발의 주요 13 개 분야(거 시경제 발전, 무역 및 송 금액 증가, 민간분야/중소 기업 개 발, 농업성장 및 식량안보, 소액대출, 인프 라개발, 관광개발, 정보통신 및 생명 과학개발, 안 전대책 프로그램, 교육, 보건, 여성권리 고양, 선 정)의 전략 수립, 정부의 정책, 프로그램, 프로젝트 의 소개 및 성과도를 점검하고 $\mathrm{PRSP}$ 의 목표와 활 동 계획들을 4 가지 전략과 1 가지 보조전략으로 나 누어 설명하고 있다. 4장은 목표달성성취 및 비용 에 관한 자료로 몇 가지 프로그램과 프로젝트의 목 표치와 달성 비용을 보여준다. 5 장은 빈곤삭감 전 략의 평가 및 모니터링에 관한 자료로, 평가의 중 요성, 과정, 절차 그리고 각 기관의 역할과 기능에 대해서 언급하고 있다 (이하 보고서 내용을 요약 정리).

\section{PRSP 수립관련 고려사항}

방글라데시 정부가 PRSP 수립을 위한 전략 구 상시 고려해야할 요인들은 아래와 같다.

\section{1) 과거의 성과 평가}

방글라데시는 독립이후 빈곤경감을 위한 정책 적 노력에 힘써왔다. 특히 초등교육, 여성 교육, 예 방접종, 소액대출, 여성 경제분야 참여, 인구조절 정책 등의 분야에서 괄목한 만한 성과를 이루었다. 
$\mathrm{PRSP}$ 는 위와 같은 과거의 성과를 고려하며 수혜 자 및 수혜지역 확대, 프로그램의 확장 등 다음의 된다.

개발과제로 나아가는 것이 바람직하다.

\section{2) 개발과제 정체현상 극복}

최근의 조사에 따르면 방글라데시는 인구정책 에서 적지 않은 성과를 이뤄냈으나 더 이상의 개선 없이 정체상태에 있음을 알 수 있다. 피임보급률의 확대로('70년대 중반 7\%에서 2000년 54\%) 합계 출산율은 1970년대 7명에서 2003년 3.3명으로 감 소되었으나 이 수치는 1993/94년부터 3.3명 수준 을 유지하고 있다. 정체현상 타파를 위한 보다 적 극적 조치가 필요한 상황이다.

\section{3) 정책의 실질 집행율 제고}

개발사업의 실질 집행율이 저조한 점이 개선과 제로 대두되고 있다. 빈곤삭감 관련 정책과 프로그 램이 부적절한 계획 등으로 착수가 지연되는 일이 빈번하며, 무엇보다 심각한 것은 프로젝트의 실패 가 방글라데시에서 빈번하게 발생되고 있어 프로 그램 이행능력(정부, $\mathrm{NGO}$ 등 사업수행자) 향상이 중요한 전략적 도전과제로 손꼽히고 있다.

이와 같은 현상은 우선, 예산 미확보 문제와 사 업계획의 미숙성에 기인하는 것으로 보인다. 2002 년 보고서에 따르면 이전 4년 동안 개발프로그램 의 집행률은 $56 \%$ 에 그친 것으로 나타났다. 더구나 이중 $15 \%$ 의 프로젝트는 전혀 집행되지 않았다. 두 번째 이유는 공무원 및 개발사업 수행자들에 대한 인센티브 및 동기부여의 부족을 들 수 있으며, 구
체 사업시행을 위한 세부시행 계획의 부재도 거론

\section{4) 개발사업의 결과 중시 - 취업율 등 향상}

빈곤경감을 위한 개발사업 추진시 '취업률' 향 상은 빼놓을 수 없는 이슈로, 개발사업이 1) 실질임 금의 향상 2) 자영업 활동 확대 3) 노동생산성 증 가 4) 농산품 및 무역증진 등을 고려하여 설계되고 추진되어야 할 것이다.

\section{5) 여성권리 강화 (Empowerment for women)}

정부는 그동안 여성권리 신장분야에서 주목할 만한 성과를 이루었다. 초중등 교육에서 여성참여 율이 확대되었으며, 경제활동분야에서의 여성참여 율도 지속적인 증가세를 보이고 있으며 이는 여성 에 대한 사회적 인식의 변화에도 영향을 주고 있 다. 그러나 아직 정부기관, 경찰서, 법원, 시장, 도 로(공공장소) 등 많은 곳이 아직도 반여성 친화적 이며 주요 분야에서의 여성 참여율은 여전히 낮아 여성권리 강화와 여성참여 프로그램 확대, 여성 노 동 생산력 확대노력 등 각 분야에서의 여성권리 신 장 필요성이 대두되고 있다.

\section{6) 소액 대출 프로그램 향상}

소액대출(micro-credit) 프로그램은 빈곤경감 대책 중 가장 뚜렷한 성과를 거둔 분야의 하나다. 이는 방글라데시 빈곤경감 프로그램에서 빼놓을 수 없는 효자 프로그램으로, 대출제도 개선 및 집 중은 빈곤경감 정책에 큰 영향을 미칠 것으로 예상 
된다. 개선과제로는 적절한 이자율을 적용한 효율 적 운영방안, 절대 빈곤층까지로 수혜층 확산, 소 액대출 프로그램을 소액 보험제도와 같은 다른 상 품과 연계, 생활의 질을 향상하는 방안 등이 고려 가능하며, 소액대출 프로그램 확산을 위해 2 가지 방안을 검토할 수 있다. 첫째는 현행 소액대출 금 액(재원) 확대이며, 둘째로 지역별(소득수준별) 맞 춤 대출 상품의 개발이다.

\section{7) 빈곤층과 여성을 위한 정치}

빈곤경감 정책이 가장 '요구' 되는 곳이 어딘지 정확하게 분석하여 수요자에게 공급되도록 집중해 야 한다. 방글라데시 정부는 여성과 아동을 주 수 혜층으로 선정하고 생활향상을 추진하고 있다.

\section{8) 개발사업의 모니터링 기준 설정}

주요 빈곤경감 관련 프로그램의 성공여부는 결 과에 의해 평가받으므로, 기준을 설정하여 프로그 램 및 정책 이행부분을 정기적으로 모니터링 해야 한다. 모니터링은 정책행동 지표, 결과지표, 중간 점검 지표를 분리하여 감시하는데 매우 유용하게 사용되고 있다.

\section{9) 교육의 질 확보}

정부는 교육의 질을 확보하는 것이 빈곤경감정 책의 수행에 중요한 역할을 할 것으로 간주하고 있 으며 학생들의 교육성과 측정과 교육 이수율 제고 를 추진하고 있다. 2002년 통계에 의하면 초등교 육 이수자의 $1 / 3$ 이 언어능력과 수학능력이 떨어지
는 것으로 나타났다(Education Watch 2002 보고 서). 또한 중등교육 이수자의 40\%만이 10-12학년 시험에 합격하고 있으며, 고등교육 및 기술 - 직업 교육의 질은 더 낮아 경제발전에 걸림돌로 작용하 고 있는 것으로 나타났다.

\section{0) 아동권리 향상 문제}

방글라데시는 아직 법적으로 '아동' 의 정의조차 일정하게 제시하지 못 하는 수준이다. 많은 수의 아동이 보건서비스, 적절 영양 섭취, 위생, 식수, 안전문제에서 혜택을 받지 못하는 것으로 나타났 으며 아동을 위한 법 제도 이행률도 저조한 편으로 나타났다. 방글라데시 전체 노동력의 $10.1 \%$ 가 아 동 노동력으로 나타났으며, 길거리 여아들이 성매 매 및 밀수에 희생자로 전락할 가능성이 높은 것으 로 나타나 아동권리 신장의 중요성이 대두되었다.

\section{1) 토지정책 및 토지 행정개혁}

방글라데시처럼 높은 인구밀도에 비해 적은 토 지를 소유한 나라는 효과적 토지운영이 중요하다. 방글라데시는 설상가상으로 극소수 인구가 토지를 점령하다시피 소유하고 있어 토지분야에 대한 문 제제기는 끊이지 않고 있다. 정부는 최근 '토지개 발 정책'을 도입하여 현 토지제도를 개혁하고, 토 지의 이용율 향상 및 농촌토지 감소 예방프로그램 을 도입하였다. 정부는 정부소유 토지, 버려진 토 지, 수용토지 등 다양한 토지 관련 정보를 제공하 는 '토지 정보은행' 을 설립하였다. 정부는 또 '토 지문서제도' (certificate of land ownership)를 도 
입하여 엉성하게 유지되어 오던 '가족 토지기록' 을 대신하였다.

\section{2) 도시지역 빈곤}

방글라데시는 빠르게 도시화되고 있는 나라이 다. 2010 년에는 도시인구가 전체인구의 $1 / 3$ 을 차 지할 것으로 예상된다. 도시민의 수입(income)은 전체 나머지 인구의 수입을 초과한 상태이다. 그러 나 무계획적 도시성장 정책, 불법 토지 사용 등 여 러 가지 문제점을 안고 있다. 효과적 도시화 전략 이 긴요하며 위생, 공공보건, 전염성 질병예방 및 빈곤여성과 슬럼가 주민들을 위한 상수, 전기, 에 너지, 교통 등이 이루어져야 한다.

\section{3) 주요 산업 인프라 구축}

지속적 경제성장을 위한 인프라 구축의 필요성이 대두되고 있다. 다카-치타공간 고속도로, 파드마 (Padma) 다리 건설, 동-남서간 철도 연결, 시내교 통망 개선, 치타공 항구 개발, 내륙수로 개발 등 주 요 인프라 개발의 장기적인 설계전략이 필요하다.

\section{4) 선진 기술 전수}

방글라데시는 섬유업등 가장 대표적인 노동집 약산업 의존국가로 노동자 해고와 같은 사태를 우 려하여 산업분야 내 기술도입을 망설여 왔다. 즉 기술 향상이 정책적으로 성장하기 어려운 상황이 었다. 현재 기술이 가장 필요한 분야는 1) 농업, 수 산업계와 2) 정보통신 분야라 할 수 있다. 농업분 야에서의 선진기술 도입은 식량 증산 등에 필수적
이며 수산업계의 기술도입은 특히 수출산업으로 양식업 분야의 빠른 성장을 예상할 수 있다.

정보통신 분야의 기술도입이 빈곤경감에 중요 한 이유는 첫째, 정보통신이 가져다 줄 일자리 창 출능력 때문이며, 두번째로 IT가 빈곤층의 역할 강 화에 촉매 역할을 하기 때문이고 셋째, 정보통신이 국민간 거리감 해소에 중개역할을 하고 있기 때문 이다. 정보통신 분야는 현재 여전히 1) 접속상태의 불안 2) 저조한 기술수준 3) 정보통신 훈련 제도 및 정보통신 전문인력의 질 부족 등 3 가지 장벽을 안고 있는 것으로 나타나 기술도입 등 지원이 필요 하다.

\section{5) 사회안전망 확대}

방글라데시인의 삶에서 위험성과 취약성은 특 히 빈곤층에게 주된 문제로 작용하고 있다. 정부는 빈곤경감 전략의 일환으로 '안전대책 프로그램' 을 시행하였다. 그러나 방글라데시는 여전히 재해, 기 근, 공공보건 위험성, 질병으로 인한 위험성을 내 재하고 있는 국가이다. 여성의 지참금 문제, 가족 제도 붕괴 문제와 같은 사회적 병폐도 수면위로 떠 오르고 있는 과제이다. 늘어나는 노인과 장애인과 같은 취약 그룹의 보호도 간과할 수 없는 문제로 포괄적인 접근이 필요한 시점에 있다.

\section{3. 빈곤경감 추진전략(PRSP)-기본전략의 설정}

방글라데시의 빈곤경감 가속화를 위한 전략 설 정에는 3 가지 과제가 따른다. 첫째는 손실을 최소 화 하면서 과거의 성과를 확대해 나가는 것이다. 
두번째는 전략 설계시 우선순위 선정을 통해 빈곤 해결을 위해 다각도로 접근하는 것이고, 세번째가 민간.공공기관 및 지방기관 등의 모든 영역에서 빈 곤과제 해결에 역량을 집중하는 것이다. 이러한 로 드맵을 위한 정책은 크게 3 가지, 「빈곤층을 배려한 경제성장」, 「인간개발」,「정치 및 거버넌스 향상」 으로 구성되어 있다.

'빈곤삭감 가속화를 위한 전략 설정' 은 4 개의 큰 전략과 1 개의 보조전략으로 구성되어 있으며 각 13 파트로 나누어져있다.

\section{〈빈곤삭감 가속화를 위한 PRSP 전략 구성 〉}

전략 1부: 빈곤층을 위한 거시경제 환경 조성

1)거시 경제 개발

2)무역 및 해외근로자 송금액 확대

전략 2부: 빈곤층의 자립을 위한 분야별 경제성장 촉진

3)민간분야 및 중소기업 개발

4)농업발전 및 식량 안보

5)소액대출(micro-credit)

6)인프라 개발 및 개혁

7)관광사업 지원

8)정보통신 및 생명공학 개발

전략 3 부: 효과적인 사회안전 프로그램 마련

9) 안전대책 프로그램

전략 4부: 인간 개발 (Human Resources Development)

10) 교육

11) 보건

보조전략 : 비주류의 사회참여 및 거버넌스(governance)

12) 여성권리 향상(Empowerment)

13) 좋은 통치(good governance)

빈곤층을 위한 거시경제 환경 조성을 위한 전략 1부에는 1) 거시경제 개발, 2) 무역 및 해외근로자 송금액 확대를 위하여 회계정책, 금융정책, 시장정 책 등 거시적 안목에서의 경제 개발을 위한 전략 설정에 대해서 기술하고 있다.

빈곤층의 자립을 위한 분야별 경제개발 전략 2
부에는 3) 민간분야/중소기업 개발, 4) 농업성장 및 식량안보, 5) 소액대출, 6) 인프라 개발, 7) 관광 개발, 8) 정보통신 및 생명공학 분야 등 빈곤층 지 원을 위한 주요 분야별 정부 목표에 대해 서술하고 있다.

한편, 효과적인 사회 안전대책 프로그램을 위한 전략 3 부에서는 9)사회 안전대책 프로그램 전략 마련과 현 방글라데시내 주요 안전대책 프로그램 을 소개하고 있다. 인적자원 개발을 목표로 하는 전략 4 부에서는 10) 교육, 11) 보건 부분에 대한 정 부의 노력과 계획을 담고 있는데 단기적 목표 달성 보다는 장기적 관점에서 인적자원 개발을 통한 빈 곤경감을 추진하고 있다.

보조전략으로는, 12) 여성의 사회참여 및 권익 향상 지원, 13) 좋은 통치(good governance)를 다루고 있으며 여성차별 근절을 목표로 한 다양한 정부의 정책목표와 여성의 사회참여 장려를 통한 빈곤경감 의지를 담고 있다. 좋은 통치는 방글라데 시내 매우 중요한 이슈로, 전반적인 정부 내부로부 터의 개혁을 통해 빈곤경감 목표를 달성코자 하고 있다.

전략 1. 빈곤층을 위한 거시경제 환경 조성

\section{4. 거시경제 개발}

\section{가. 예산 및 회계 정책}

1) 회계의 투명성 및 빈곤층 지원예산 확대 
- 부채 관리

정부의 국채발행 규모는 2001 년 $\mathrm{GDP}$ 의 $3 \%$ 에 서' 05 년 $\mathrm{GDP}$ 의 $1 \%$ 로 감소되었으며 다카화 가 치안정과 금융안정성 확보를 위해 각 경제부처 를 연결하는 '내부통제 체제' (Internal Control Manuel : ICM)가 완성되었다. 재무부내에 공 공채무 관리를 전담하는 조직이 신설되어 효율 적인 국채관리가 이루어 질 것으로 보인다.

- PRSP는 회계년도 2005 '07기간중 재무부 내 ‘금융자원 및 부채관리 담 당과’ 가 조기 정착되도록 지원하는 것을 목표로 설정함.

\section{- 예산 집행의 효율성 제고} 정부는 2006년부터 4 개 부처(농림부, 교육부, 복지부, 여성-아동부)에 '중기예산 편성' $(\mathrm{MTBF})$ 제도를 도입하였다. 또한 효과적인 예 산 집행과 감독을 위해 모든 정부부처에 예산 관리 위원회(BMCs)를 설치하도록 하였고, 2005년 7월에는 '공공지출 관리매뉴얼' 을 발 행, 예산집행의 효율성을 강화하였으며 예산편 성시 빈곤층 및 여성을 우선적으로 배려하도록 하였다.

- PRSP는 회계년도 2005 ' 07기간중 예산 관리위원회가 각 단계별 예산집행 내역을 점 검하도록 권고함. 또한 '중기예산 편성제도' (MTBF)는 2007년부터 보건복지부등 6 개 부처로 확대하고 점차 전 부처로 확대할 계 획임.

a 예산집행의 투명성 증진(감사제도 개선) 정부는 투명하고 효율적 회계시스템 정립을 위
해 감사제도 및 관련 조례안들을 개정하였으며 감사요원을 대상으로 전문훈련을 실시하는 등 감사원의 감사내용이 질적으로 향상되고 있다.

- PRSP는 회계년도 2005 ’07 기간중 국가 감사업무의 향상을 위하여 관련제도개선, '공공회계 위원회' 설치 등을 목표로 설정함.

- 또한 PRSP는 동 기간중 모든 부처에 '내부 통제체제' (ICM) 정착을 제도화하여 회계관 리와 통제의 효율성을 높일 것을 목표로 설 정함.

\section{- 빈곤층 및 여성대상 예산배정 확대} 정부의 빈곤층에 대한 예산은 2003 년 GDP의 $6.02 \%$ 에서 2006년에는 $\mathrm{GDP}$ 의 $8.39 \%$ 로 증가 되었다. 재무부에는 전담부서 (General Economic Division)를 두고 빈곤층 지원을 위 한 예산확대 및 배정의 효율성을 높이는데 주 력해 왔다. 또한 빈곤 여성지원을 위해 '빈곤여 성지출예산' (Recurrent, Capital, Gender and Poverty : RCGP) 모델을 개발, 빈곤여성관련 예산지출의 효율성을 검증하는 시스템을 개발 해 왔다.

- PRSP는 회계년도 2005 ’07 기간중 빈곤 층 지원예산을 매년 확대해나갈 것을 천명하 였고, 빈곤층대책의 부처간 연계강화를 목표 로 설정함.

- 또한 동 기간중 빈곤정책 지원을 위한 정보 분석 능력을 강화하고, 예산집행의 효율성 검증을 위한 모델링 능력을 강화할 것을 목 표로 설정. 
2) 세금제도 개혁

\section{- 징수율 향상}

정부는 그간 징수율 향상을 위해 '세금제도 개 혁위원회' 를 운영하여 왔으며, 2005년 위원회 의 제안에 따라 공평과세 및 비과세 항목 축소 등 세금 제도 개혁을 위해 노력해 왔다.

- 회계년도 2005 '07을 위한 PRSP에는 세 금제도 개혁조치들을 지속 추진할 것을 명시 하는 한편, 직접세와 부가세(VAT) 비율을 점 진적으로 늘릴 것을 목표로 정함.

- 또한 동 기간중 세입 증대를 위해 비과세 세 목 축소를 강력히 추진 할 것 을 천명함.

\section{- 조세행정 향상}

정부는 외부의 회계 전문기관을 활용, 세금누 수 및 탈루행위를 점검하도록 하였고 조세행정 개선을 위한 '조세행정 개혁안' 을 실행해 왔다. 국세청 직원들의 전문화 및 세금서비스 향상을 통하여 통관, VAT, 소득세 분야의 행정능력을 향상시키고 있으며 '대규모 납세 담당과' (Large Taxpayer' s Unit)를 설치, 1,000여명 에 이르는 대형 납세자를 별도 관리하고 있다. 또한 세금 누수 추적을 위한 '중앙조사 위원회' 가 운영중에 있으며, 생수, 소다수, 화장비누와 같은 제품에 새롭게 VAT를 적용하는 등 세목 확대를 추진중이다.

한편, 관세행정 향상을 위하여 세관에 '자동통 관 데이터 시스템' 을 운영하여 통관행정의 투 명성을 강화하고 있으며, 관세 수입을 확대하 기 위해 노력중이다. 정부는 관세행정 전문화
를 위해 세관의 각종 설비를 현대화하는 한편, 치타공 세관에 세무공무원 훈련센터를 설립하 는 등 세무행정 전문화를 위한 노력이 지속되 고 있으며, 세금 옴브즈만이 시행중에 있다.

- PRSP는 회계년도 2005 '07 기간중, 탈세 를 최소화하고 세입증대를 위해 관세, VAT, 소득세 담당 부처간 자료 교환 및 공유 제도 를 도입하고 지방세무서와 국세청간 네트워 킹 시스템을 구축할 계획임.

- 또한 세원확보를 위한 '대형 납세자 담당과' 활동 확대, '중앙조사 위원회' 역할 강화도 추진 목표로 설정.

- 부가세 적용항목 확대, '자동통관 데이터 시 스템' 의 운영정착도 목표로 삼고 있음.

\section{나. 금융 개혁 및 경쟁력 강화}

\section{1) 금융분야 관리능력 향상}

최근 정부는 은행의 유동성확보 비율(Statutory Liquidity Ratio:SLR)을 $16 \%$ 에서 $18 \%$ 로 상향 조 정하고 지불준비율(Cash reserve requirement) 도 $4.5 \%$ 에서 $5 \%$ 로 상향조정하여 인플레 압력을 낮추고 자금시장의 안정성을 확보하고자 하였다. 예금이자율이 하락하였으며 재무부 국채 (Treasury Bill) 이자율도 조정되었고 환매계약 (Repo)과 반환매계약(Reverse Repo) 제도를 도입 하였다. 국채 유통시장 활성화 조치 등 정부의 금 융정책을 지원하기 위한 프로그램들이 시행되었 으며 빈곤층을 위한 대안적 예금 기관들이 제안되 었다. 
- 회계년도 2005 '07을 위한 PRSP에는 빈 곤층을 위한 대안적 금융기관 개발, 은행간 금융시장 설치, 은행간 협력 증진, 금융의 인 터넷활용 확대, 인재양성 등 방글라데시 은 행의 현대화가 목표로 설정됨.

\section{2) 국영 상업은행 개혁}

정부는 경쟁력 없고 적자상태인 국영 상업은행 의 수를 지속적으로 줄여왔다. 현재 남아있는 4 개 의 국영 상업은행(루팔리은행, 아그라니은행, 자나 타은행, 소날리은행)에 대하여는 특별 회계감사를 실시하는 등 관리감독을 강화하고 있다.

- 회계년도 2005 '07을 위한 PRSP는 금융개 혁 전략의 성공적 이행을 목표로 하고 있으 며, 은행별로 금융관리 전문가 확보, 적자상 태인 국영 상업 은행정리 등을 목표로 설정.

\section{3) 국영기업 개혁}

정부는 국영기업 개혁에 목표를 두고, 가능성 있는 기업을 집중지원하는 한편, 부실기업에는 국 영 상업은행의 신규 대출을 축소하는 둥 국영기업 의 효율성 및 경쟁력 강화를 위해 노력하고 있다. 이와 함께 기업의 경영활동을 정밀하게 모니터링, 회계연도 2003년도의 경우, 황마생산 공장을 포함 28개의 부실기업이 정리되었다. 2001.11 2005.7 사이 17 개의 공장이 업종전환 되었고 4 개의 기업 은 민영화되었으며, 현재 국영제조업체 25 개가 민 영화 리스트에 올라 있다.

- 회계년도 2005 '07을 위한 PRSP에는 국
영기업의 적자 감소와 민영화 촉진, 국영기 업대상 예산지원 축소 등이 목표로 설정됨.

\section{4) 자본시장 활성화}

국내 증권시장 활성화를 위하여 주식 발행촉진 및 자본시장의 안정화 정책이 추진되었다.

- PRSP는 회계년도 2005 '07기간중 자본시 장 안정 강화, 법규정 정비, 세법 개정을 통 한 국내 자본시장 활성화를 목표로 설정함.

\section{5) 금융위기 예방을 위한 감시제도 향상}

정부는 금융위기 예방을 위해 은행에 내부 감시 제도를 도입하였으며 최소 자본비용을 2 억다카에 서 10 억 다카로 증액되었고, 개인대출 상한선을 절 반으로 줄였다.

- 회계년도 2005 '07을 위한 PRSP는 은행 의 감시제도 강화와 감사의 전문을 향상시키 는 것을 목표로 설정함.

\section{5. 무역활성화 및 해외근로자 송금 확대}

\section{가. 섬유수출 지원}

\section{1) 수출 현황}

정부의 수출절차 간소화 정책, 품목제한 완화, 수입관세 철폐 및 하향 조정, 경쟁적 환율 등은 결 과적으로 방글라데시 제품의 수출증대로 나타났 다. 1990년대 수출 신장율은 매년 평균 $12.5 \%$ 로 $\mathrm{GDP}$ 성장률 $4.8 \%$ 와 1980 년대 수출신장율 $3.9 \%$ 와 비교해 보아도 높은 수치이다. GDP 대비 무역 
비율은 1980년대 중반 17\%에서 2000년 33\%로 증 가하였다. 방글라데시는 수출의존도가 높은 국가 로 빈곤경감을 위한 경제성장에서 수출 촉진은 중 요한 의미를 가진다.

\section{2) 섬유업 수출 집중 및 수출저해 요인}

\section{- 섬유업 수출 및 $\mathrm{MFA}$ 철페}

방글라데시의 섬유제품 수출은 전체 수출의 $75 \%$ 를 차지하는 등 수출 분야에서 독보적인 존 재이다. 그동안 섬유업계의 수출은 $\mathrm{MFA}$ (다자 간 섬유협정) 제도의 수혜를 받으며 꾸준한 성 장세를 보여 왔으나 2004년말 MFA 철페되었 으며 방글라데시는 중국, 인도, 터키 등과 $\mathrm{EU}$ 시 장에서 힘겨루기를 해야 할 것으로 추정되고 있다. 조사에 따르면 MFA 철폐 이후 방글라데 시 수출이 최대 $50 \%$ 정도 감소(이는 GDP의 $2.3 \%$, 전체 고용의 $13 \%$ 에 영향을 줌)할 것으로 예측된다.

\section{- 미국시장의 높은 관세율}

미국으로의 섬유 수출에 부여된 높은 관세율(평 균 $16.5 \%$ )도 방해요소로 작용하고 있다. $46 \%$ 에 달하는 방글라데시 의류 수출제품은 평균 $15.120 \%$ 의 관세를 적용받고 있으며 $13 \%$ 정도 가 $25 \%$ 이상의 관세를 적용받는 것으로 나타 났다.

\section{- $\mathrm{EU}$ 시장의 원산지 규정}

$\mathrm{EU}$ 는 최빈국(LDC)에게 무관세 혜택 및 수량제 한 비적용 등 방글라데시는 $\mathrm{EU}$ 시장에서 혜택 을 받고 있다. 그러나 $\mathrm{EU}$ 시장에서도 원산지
규정정책(Rules of Origin : ROO)의 시행으로 여파가 있을 것으로 예상되어 지속적 수출 신 장이 불확실한 형편이다.

\section{3) MFA 종료후 섬유수출 촉진 정책}

\section{- MFA종료 대비 프로그램}

정부는 $\mathrm{MFA}$ 종료후의 섬유산업 육성을 위하 여 ‘국가 조정 위원회' (NCC)를 설립하였다. 동 위원회는 원산지 규정, $\mathrm{SAARC}$ 역내 무역활성 화, 수출인프라 개선 등에 관해 세부 제안서를 작성하였고 의회는 상당수의 제안서를 승인하 였다. 방글라데시 상무부는 미화 4천만불 상당 의 'MFA종료후 프로그램' (Post-MFA Action Program)을 입안하여 MFA 철폐로 인한 부정 적 영향들을 최소화 하는데 노력하고 있다.

\section{- 섬유 수출증진 프로그램} 정부는 섬유업 수출경쟁력 향상지원을 위해 6 개의 프로그램을 준비하였다. 먼저, (1)생산기 술 및 품질 향상계획(SQDP)은 섬유류 품질향 상, 생산관리, 마케팅, 통관절차 등 7 개 분야에 서 경쟁력을 강화하기 위해 추진중이다. (2)퇴 직여성 노동자 지원 프로그램(DWRP)은 수출 감소로 퇴직한 섬유업종사 여성노동자들의 재 활 및 재취업 훈련프로그램이다. 정부는 퇴직 노동자 훈련 및 재취업을위해 2006년에 2억 다 카의 예산을 배정하였다. (3)중소기업 수용력 강화 프로그램(SECEP)은 중소기업의 기술력 개발 프로그램이며 그밖에 (4)제품의 질향상과 비용절감을 위한 기본 기술지원 프로그램 (5)수 
작업 분야 생산성 향상 지원 프로그램 (6)관련 사업간 연계지원 프로그램 등이 있다.

\section{- 미국 시장수출 대비}

미국은 단일시장으로는 가장 큰 방글라데시 섬 유 제품 수출 시장이다. 정부는 미국정부와 수 출관련 무관세혜택을 받기위한 노력들을 새롭 게 시작하였다. 이와 관련 정부는 '방글라데시 섬유수출협회' (BKMEA)와 공동으로 미국에 섬유제품 무관세 혜택을 부여받기 위해 로비스 트를 선임하였다. 그밖에 수출장애 요인을 밝 혀내고 효과적으로 차단할 수 있는 방안이 구 상 되었으며, 항구 및 통관 제도의 개선 및 향 상을 위한 조치들도 시행되었다.

- 회계년도 2005 '07을 위한 PRSP에 따르면 정부는 $\mathrm{EU}$ 의 원산지 규정 (ROO)이 방글라 데시에 미칠 영향들에 대한 연구를 진행시키 도록 결정하고, 선진국 원조기관을 통한 섬 유기술 향상, 퇴직(여성) 노동자 훈련 프로그 램 실시할 것을 목표로 설정함.

- 노동자훈련 프로그램을 통해 약 3 만 여명의 퇴직노동자들이 재활훈련을 받도록 하고 노 동자 은행과 BRAC은행을 통한 최대 7만5천 다카(약 $\$ 100)$ 에 상응하는 대출 제도를 마련 할 예정임.

- 정부는 선진국과 후진국 시장에서 방글라데 시산 섬유제품의 무관세 혜택을 위한 캠페인 을 진행시킬 예정이며 화물수송 비용도 현재 $10,000 \sim 20,000$ 다카(톤당)에서 1,250 다카 (약 $\$ 20)$ 로 축소할 것을 목표로 설정.

\section{나. 수출 다변화 및 국제경쟁력 향상}

정부는 동 유럽지역으로의 수출시장 개척을 위 한 조치를 시행하였고 수출 확대를 위한 ' 3 개년 (2003-2006)수출정책' 및 '수출 진흥 협의회’ (Business Promotion Council)를 설립, 수출기업 인센티브제 실시 등 수출기업의 경쟁력 향상을 위 해 노력하였다. 섬유수출 업체에는 정책자금지원 을 통하여 $\mathrm{EU}$, 캐나다, 미국 등 주요 수출시장에 서 시장 점유율을 유지.강화코자 하고 있다. 방글 라데시는 이미 SAFTA, BIMSTEC, TPS-OIC 등 3 개의 지역 자유무역 협정에 조인한 상태이다. 중 소기업의 수출 증진을 위해, 정부는 다양한 인센티 브 제도를 시행하였다.

- 회계년도 2005 '07을 위한 PRSP에는 아프 리카 및 동남아시아에 수출 개척단을 파견하 는 조치를 포함하고 있으며, 더 많은 수출항 목에서 인센티브 적용을 목표로 함.

- 수출가공공단(EPZ), 방글라데시 관세위원회 등 수출유관 기관의 개혁작업을 기간중 완료 할 예정임.

- SAFTA, BIMSTEC, TPS-OIC등 지역불럭에 서 국익 증진을 위해 별도의 협상팀을 구성함.

\section{다. 해외근로자 송금 및 $\mathrm{FDI}$ 증진}

정부는 외환부족 사태를 완화하기 위해 500만 에 이르는 자국 해외근로자의 경비송금제도 정비 에 적극 나서고 있다. 국영은행에 ‘송금 지원부’를 설치하고 공식적 채널을 통한 외환 송금 증진에 노 력중이다. 또한 재무부 내 감사팀을 운영하여 송금 
자들의 민원해결을 지원하고 있다.

- 회계년도 2005 '07을 위한 PRSP에는 법적 및 공식적인 채널을 통환 외환 송금이 이루 어지기 위한 노력을 지속적으로 시행할 것을 목표로 정함.

- 또한 돈세탁 감시활동의 강화로 불법송금 및 암시장 확대 등 외환의 비정상적 흐름을 예 방함을 목표로 함.

한편, 외국인 직접투자(Foreign Direct Investment: $\mathrm{FDI}$ )는 경제발전 초기에 섬유업 발 전 등에 기여하여 왔으며 최근에는 에너지. 광물자 원 개발에서 중요한 역할을 하고 있다. FDI는 외환 안정 뿐 아니라 일자리 창출, 기술이전, 경영관리 기술 향상, 사회변혁 등에 있어 중요한 부분이다. 방글라데시의 해외투자제도는 비교적 자유로운 편 이나 투자규모는 1990년대 년간 미화 2억불 수준 으로 투자분야도 가스, 에너지, 통신분야가 중심으 로 제조분야의 $\mathrm{FDI}$ 는 저조하였다. 최근 수출가공 공단(EPZs)내 투자가 빠르게 성장 $2002 \sim^{\prime} 03$ 년 1 억3천불, 이중 $80 \%$ 가 해외직접투자액)하고 있으 나 여전히 연평균 $\mathrm{FDI}$ 수치는 낮은 편이다.

\section{전략 2. 빈곤층의 자립을 위한 분야별 경제성장 촉진}

\section{6. 민간부문 및 중소기업 발전}

\section{가. 정치적 환경 조성}

민간 부문 및 중소기업 발전을 위해 정부는 법
적기본 틀을 제공하고 민간부분의 자립능력 향상 을 지원하였고, 중소 민간기업의 수출 활성화를 위 한 '무역관련 제도' 개선을 위해 노력하였다.

- 회계년도 2005 '07을 위한 PRSP에는 다른 국가의 경험을 연구하여 '민간분야 개발전 략 을 입안하는 것을 목표로 하고 있음.

- 또한 민간부문 발전을 위해 국회의원과 민간 전문가들이 공동으로 참여하는 '국가 위원 회 설립을 추진하며, 노동법 개정도 추진 예 정임.

\section{나. 중소기업 활성화를 위한 인프라 설비 향상}

인프라설비 향상을 통한 중소기업 경쟁력 향 상을 목표로 여러 가지 계획들이 시행되었다. 인프 라건설이 주로 국가경제 발전을 위해 추진되지만 방글라데시의 허술한 인프라는 특히 중소제조 업 자에게 큰 영향을 준다(교량, 대중교통의 부재로 운송비등 부담가중). 자무나철도교량 건설공사 (Jamuna Bridge Railway Link Construction Project)가 2006년 6월 완성을 목표로 1997년 7월 부터 시행되었으며, 다카-치타공간 고속도로 공사 에 말레이지아 '아즈맛 콘소티움' 사와 한국의 '룩 손 글로벌' 사 등 2 개국의 제안서가 제출되었다.

- 회계년도 2005 '07을 위한 PRSP에는 주요 항만의 현대화 및 항만청 관리. 경영개혁, 민 간투자 항구 설치, 다카-치타공간 고속도로 건설, 다카-락샴간 Cord Line 프로젝트 실 시, 자무나 철로 프로젝트 시행 등이 목표로 설정되어 있음. 


\section{다. 중소기업 활성화를 위한 인재 및 기술개발}

중소기업 활성화를 위한 인재 및 기술개발을 위해서 회계년도 2005 '07 빈곤삭감 보고서에는 '교육 및 훈련 프로그램 교과과정' 이 민간분야의 수요를 반영하도록 하고, 훈련 및 기술개발 활성 화, 인턴 쉽 촉진 등을 목표로 설정하고 있다.

\section{라. 취업률 향상}

경제성장과 함께 고용기회가 확대되었으며, 고용인구도 1990년 3,480명에서 1995 ' 96년 3,900만명으로, 2001 ’ 02년에는 4,430만명으 로 증가되었다. 그러나 새로운 일자리 창출면이 나 다양성에서 저조한 성과를 보였으며 실업률 이 1999 2002년간 4.3\% 수준을 기록하였다(비 공식적으로는 $20 \%$ 를 넘는 것으로 예상). 정부는 빈곤층에게 고용기회 확대, 임금 향상, 비공식적 분야에서의 고용 확대 등 취업률 향상을 위한 노 력을 기울여 왔다. 방글라데시 정부는 2008년까 지 총 고용 인구를 5,800 만명으로 확대하는 한 편, 신규 고용 창출도 330 만명을 목표로 삼고 있다.

〈 방글라데시 정부의 고용향상 추진계획 2003 2008〉

\begin{tabular}{l|c|c|c|c|c|c}
\hline \multicolumn{1}{c|}{ 구 분 } & '03년 & '04년 & '05년 & '06년 & '07년 & '08년 \\
\hline 총고용인구(백만명) & 44.30 & 46.75 & 48.92 & 51.69 & 54.75 & 58.08 \\
농촌지역 고용 & 33.60 & 34.96 & 36.64 & 38.30 & 40.35 & 42.57 \\
도시지역 고용 & 10.70 & 11.77 & 12.28 & 13.39 & 14.40 & 15.51 \\
새로운 일자리 & - & 2.43 & 2.19 & 2.77 & 3.06 & 3.33 \\
고용인구 (백만명) & & & & & & \\
농촌지역 고용 & - & 1.36 & 1.68 & 1.66 & 2.05 & 2.22 \\
도시지역 고용 & - & 1.07 & 0.51 & 1.11 & 1.01 & 1.11 \\
\hline
\end{tabular}

\section{마. 기업 지원서비스 향상}

정부는 기업지원 서비스 향상을 목표로 정보 및 데이터 베이스를 제공하여 왔으며, 해외직접 투자(FDI)를 확대하기 위해 다방면으로 노력하 였다. 특히 생산제품의 질 향상을 위해 품질기준 설정 및 품질관리기술 향상 등 조치들도 시행되 었다.

- 회계년도 2005 '07을 위한 PRSP에는 방글 라데시 통계청(BBS) 내 '산업 통계 분야'를 강화할 것을 목표로 설정함.

- 또한 국제적 기준에 부응하는 품질검사 기준 설정 및 품질검사청(BSTI) 기능강화, 민간투 자 등록제 시행을 통한 기업지원 서비스의 질 향상을 목표로 설정.

- 더불어 기업지원활동 원스톱 서비스를 위해 방글라데시 투자청(BOI)과 방글라데시 수출 가공공단 협회(BEPZA)를 하나의 기관으로 통합하는 것을 추진할 예정이며, 수출진흥공 단(EPZ)만을 위한 서비스 지원활동을 통하 여 수출진흥 공단의 외국인 투자 및 기술이 전 능력을 강화할 예정임.

\section{바. 민간분야에서 여성의 경제활동 참여 확대}

민간분야의 여성참여율을 현재의 $25 \%$ 에서 $50 \%$ 로 확대하고, 여성 기업인의 증가를 위해 정부 는 여성 중소기업인에게 대출을 지원하고 있으며 직업관련 전문 기술훈련을 제공하여 전체적으로 여성의 수입이 늘어나도록 노력하고 있다. 여성 무 역인들을 위한 비즈니스 인큐베이션 및 비즈니스 
센터가 설립되었고, 무역 전시회 등에서 여성들을 위한 장소 및 필요설비를 지원하는 방안도 추진중 에 있다. 그 외, 여성대상 사업 발굴, 기업운영상의 재정적, 기술적 지원 등 여성 기업의 성장을 장려 하고 있다.

- 회계년도 2005 '07을 위한 PRSP에는 여성 의 관점에서 '산업 및 중소기업 정책' 을 재검 토하는 방안이 제시됨.

- 정부는 동 기간중 신설 산업에 여성 노동자 를 우선 고용할 것을 권고하고 여성 노동자 들의 기업활동 참여를 확대해 나갈 예정임.

- 또한 여성 중소기업에 인센티브를 제공하고 섬유업계 여성 노동자들에게는 기술 훈련을 제공하는 등 여성기업인 키우기에도 집중할 예정.

- 한편, 무역 협상대표단에 여성대표를 포함하 고 국내 및 해외 무역 전시회에 여성 기업인 참여를 촉진한다는 목표를 가지고 있음.

\section{7. 농업성장 및 식량 안보 증진}

\section{가. 농산품의 생산성 증가 및 식량안전 확보}

정부는 2006년까지 쌀 생산을 2천9백만 톤으로 증산하고 원예분야 및 다른 농산품의 생산성 증가를 목표로 ‘국가 농업정책’ (National Agriculture Policy)과 '행동 계획안' 을 발표하였다. 그외, 쌀, 밀, 옥수수, 감자, 과일, 야채 등 필수농산품 생산 량 증대 및 빈곤층의 영양섭취 향상을 목표로 1997년에 ‘국가 식량 및 영양 정책' 을 제정하였다.
또한 정부는 정확한 정보 수집과적절한 식량정보 활용을 위해 '식량안보 및 취약성 탈피 제도' (FIVIMS)를 운영중에 있다.

- 회계년도 2005 '07을 위한 PRSP에는 식량 안보 증진을 위한 '행동 계획안' 에 따라 세부 이행 프로그램들을 개발하도록 목표가 설 정됨.

- 또한 빈곤층의 실질적 영양 개선을 위한 이 행과제들도 설정됨

\section{나. 수산 및 축산업 생산성 증대}

수산 · 축산업 및 가금류의 사육 활성화를 장려 하며 정부는 축산정책을 재검토, 관련 분야에 세금 우대 및 통관상의 특혜를 부여키로 하였다. 이와 별도로 축산/가금 분야 전문가 육성을 위해 노력 하였다.

- 회계년도 2005 '07을 위한 PRSP에는 각 분야별 연구가 활발히 진행되고

관련 기술지원 및 예산배분이 확대되도록 목표 로 설정함.

\section{다. 농업분야에 여성참여 증대}

농업 분야에서의 여성참여 확대를 목표로, 정 부는 농업분야에서 여성의 농업기술 지원, 여성이 재배한 농산물의 마케팅 지원 등 여성참여를 고양 시키기 위한 여러가지 노력을 취하였다.

- 회계년도 2005 '07을 위한 PRSP에는 여성 참여 확대를 목표로, 여성 중심의 '농업정책' 수립, 주요 여성참여촉진 프로그램의 예산확 
대 편성, 과부, 이혼녀 등 빈곤 여성들에 대 한 정부소유 토지 지원, 긴급 식량지원, 농업 대출 지원, 지원금 규모 확대 등을 목표로 설 정하고 있음.

\section{라. 식량 안보 증진}

식량안보 확보를 목표로 정부는 1997년에 '국 가 식량 및 영양정책' 을 발표하였으며, 동 정책하 에 식량안보 관련 활동계획을 추진하였다. 정부는 다양한 농업개발 정책과 식량증산 프로그램 및 농 촌 보조금지원 정책을 시행하고 있으며, 수산 - 축 산업 생산성 향상도 지원하고 있다. 민간분야에서 도 식량관련 무역이 가능하도록 허가되었으며, 식 품관련 수입절차를 완화하였다. 또한 식량안보 확 보를 위한 인프라 개발에 개발사업의 우선 순위를 두었다. 식량 및 긴급재해부(Food and Disaster Ministry)는 상황에 맞춘 식량분배 정책을 도입하 였으며 공개시장 정책 등 식량안보를 위한 정부의 노력이 지속되었다.

- 회계년도 2005 '07을 위한 PRSP에는 식 량안보 관련 프로그램에 예산이 확대 편성될 예정이며, 새로운 '농산품 확대 정책' 을 실시 할 예정임.

- 식량관련 민간무역 활성화, 식품보관 관리기 술 현대화, 신속한 식량분배를 위한 활동계 획안이 마련될 예정임.

- 나아가 동 기간중 '식량안보 활동계획' (Food Security Action Plan)을 제정하고 '국가 식 품안전 의회' (National Food Safety
Council)를 설립하여 제품안전 및 위생기준 을 강화하고 식품안전 행정 일원화, 농산품 보험제도 등의 도입을 목표로 설정함.

\section{8. 소액 대출 (micro-credit) 활성화}

빈곤삭감을 위한 정부의 노력은 다양한 분야에 서 이루어져 왔다. 정부는 소액 대출을 통해 보다 구체적으로 빈곤층의 빈곤경감을 달성하고자 노력 하고 있다. 정부는 공공기관, NGOs와 연계하여 소액대출 프로그램을 확대하고 있으며, 극빈층에 게도 혜택이 돌아갈 수 있도록 수혜자층의 확대노 력을 병행하고 있다. 한편 정부는 영세 자영업자가 보다 많은 돈을 무담보로 융자받을 수 있도록 지원 하는 정책을 도입하였으며, 융자금 상환이 보다 융 통성 있게 이루어지도록 개선하였다.

- 회계년도 2005 '07을 위한 PRSP 목표에는 정부-NGO간 협력 확대, 주요 소액대출 수 혜자 발굴 및 전달 시스템 강화, 무담보 대출 정책 확대, 영세기업대출 지원 및 생산품 다 양화 추진, 특수화된 서비스 기관 설립 지원, 대출 확대를 위한 자본확대 지원, 대출 이자 율의 축소 등이 있음.

\section{9. 인프라 개발 및 개선}

\section{가. 전력분야-방글라데시 에너지 개발청(BPDP)}

전력분야는 산업발전에 있어 가장 중요한 요소 이나 방글라데시의 전력분야는 위기에 서 있다. 그 동안 정부의 정책지연으로 인하여 신규 발전소 건 
설도 늦어져 06년도에만 $3,000 \mathrm{MW}$ 의 공급차질이 발생할 것으로 보이며, 이는 전체 전력생산의 $40 \%$ 에 해당하는 것이다.

정부는 에너지산업 경쟁력 강화를 위해 '에너지 가격 정책 (Power Pricing Framework)을 수립하 였으며 6 개월마다 에너지 요금을 수요량에 따라 변경하고 있다. 또한 에너지 분야 개혁 및 발전안 을 담은 '3개년 발전전략 및 개혁안' 이 수립되었 고 '에너지 위원회' 가 설립되었다. 경영효율이 떨 어지는 Ashuganj 발전소를 민영화하였으며, 남부 및 북부지역의 에너지 송배전회사 설립계획이 승 인되었다. 또한 잠재 발전용량을 최대 $7,000 \mathrm{MW}$ 로 확충하는 것과 실 발전용량을 $5,000 \mathrm{MW}$ 로 확 대하고 송배전선을 $47,000 \mathrm{~km}$ 로 확대 하는 것을 목표로 설정하고 관련 프로젝트를 시행하였다.

- 회계년도 2005 '07을 위한 전력분야 PRSP 에는 전기요금 결정절차를 보다 합리화하고, 발전소 운영 적자를 $21 \%$ 축소하는 것을 목표 로 설정함.

- 또한 전력설비 수입관련 관세율을 합리화 하 고 발전, 변전, 송전 등 각 분야별 기술향상, 에너지 분야의 비리척결을 위해 감사제도를 도입함을 목표로 하고 있음.

\section{나. 도로 및 고속도로 확충}

정부는 $2,300 \mathrm{~km}$ 에 달하는 새로운 도로건설과 $1,350 \mathrm{~km}$ 도로보수, $11,000 \mathrm{~m}$ 다리 건설, $2,000 \mathrm{~m}$ 의 다리 재건설, $1,500 \mathrm{~m}$ 의 고가도로 건설을 목표 로 설정하고 실행하고자 하였다. 정부는 '국가토
지·교통 정책 초안을 승인하였고, 효과적 도로 관리를 위한 전담부서로 도로 및 고속도로과 (Road and Highway Department: RHD)의 사업 계획과 관련 매뉴얼이 마련되었다. 고속도로의 차 선을 넓히는 확장공사와 도로성능 개선 및 향상을 위한 재공사가 이루어졌다. '도로보수 기금' 설립 을 위한 법안의 초안이 승인을 기다리고 있는 중이 며, 정기적인 도로점검과 수리가 지속되었다. 주요 도시에 행인들을 위한 인도가 만들어졌으며, 2 개 의 고가도로가 공사중에 있다. 도로 표지판과 표지 판 매뉴얼이 작성되었으며, 도로안전을 위한 프로 젝트가 시행되었다.

- 회계년도 2005 ' 07을 위한 PRSP에는 1925년에 발표된 '고속도로법' 의 개정, 도로 건설 민간투자 유치, 도로분야 마스터플랜 (Master Plan) 일원화 등을 목표로 하고 있음.

- 또한 현재 공사중인 고속도로 확장공사 완 성, 다카시내 고가도로 및 인도공사 완성 등 이 목표이며 교통수단과 도로의 현대화를 위 해 노력이 지속될 예정임

- 나아가 향후 다카-치타공간, 다카-쿨나간, 다카-실렛간, 다카-탄가일 간 도로를 4차원 으로 증축하는 공사가 진행될 예정이며, 다 카-치타공간 고속도로 공사, 다카 시외에 원 형 도로(ring road) 공사 등을 추진예정임.

\section{다. 항공분야}

방글라데시 항공사인 '비만 항공사' 는 점차적 
으로 성장추세에 있지만 여전히 여러 가지 문제점 을 안고 있다. 정부는 항공분야에서의 인프라 향상 을 목표로, 노후된 $\mathrm{DC10}-30$ 과 $\mathrm{F}-28$ 기의 항공기 교체를 통한 항공분야의 현대화를 이루고자 하였 다. 현재 2대의 DC10-30의 추가 임대 절차가 진 행 중에 있다. 우즈벡 항공사, 말레이시아 항공사, 사우디 아라비아 항공사들과 함께 공동으로 화물 서비스를 제휴하여 항공운송능력이 증대되었다.

- 회계년도 2005 ' 07을 위한 PRSP에는 항공 기 구입을 위한 노력이 지속될 것이고 더 나 아가 방글라데시 항공을 세계적인 수준으로 끌어올리는 ‘비만 프로젝트' (Project Biman) 가 시행될 예정임.

- ‘투자보장 정책' 을 비롯하여 항공분야에 민 간참여를 장려하고, 중동 및 다른 국가로의 비행 횟수를 확대할 예정

- 그 밖에 항공운송 절차 간소화 추진, 농산물 등 신선식품(perishable export) 운송이 가 능하도록 외국 항공사 유치도 추진 예정.

\section{라. 교통수단 분야}

정부는 교통수단 인프라 향상을 목표로 200여 개의 단층 및 복층 버스를 수리하였고, 7 개 지역에 자동차 정비센터를 설립하여 기술자들의 기술향상 을 장려하였으며, 각 교통수단별 요금확정 및 속도 제한 제도를 실시하였다. 한편 지난 1 년간 450,000 개의 운전면허증 갱신 발급, 대중교통안전 캠페인 및 영상물 제작 등 도로안전 인지도 확산을 위해 노력하였다.
- 회계년도 2005 '07을 위한 PRSP에는 최소 7개 주요지역에 과속 및 과중 트럭단속을 위 한 하중측정기 설치가 예정됨.

- 또한 다카시내에서 3 륜 $\mathrm{CNG}$ 택시와 2륜 인 력거(릭샤)의 도로주행 제한 및 단계적 철폐 를 추진예정.

- 다카시내 20년 이상된 노후버스와 25년 이 상된 트럭의 사용을 금지할 예정

- 600,000개의 코팅된 면허증 발급을 목표로 하고 있으며, 도로안전교육 캠페인을 전 방 글라데시로 확산하는 방안을 구상중.

\section{마. 항만 분야 - 치타공 항만청}

치타공 항구내 신설 계류지역(mooring areas) 에 $1,000 \mathrm{~m}$ 규모의 정박 컨테이너 터미날 건설을 목표로 최근 치타공(방글라데시 제2도시 이자 항 구도시)에서 공사가 준비중에 있다. 관련 터미날을 위한 토지구입 절차가 진행 중에 있으며, 82 개의 컨테이너 운반기 및 59 개의 가교크레인 구입 절차 도 진행 중에 있다.

- 회계년도 2005 '07을 위한 PRSP에는 항만 분야 인프라 향상을 위해 항구의 수용능력 강화, 항만서비스 향상을 위한 근거리 연결 도로공사, 오래된 컨테이너 계류지역 재공사 실시를 목표로 설정함

- 또한 항만행정 운영효율화를 위해 포괄적 전 산시스템 도입, 운송 및 통관절차와 서류검 사 현대화 등을 주요 목표로 설정함. 


\section{0. 빈곤경감을 위한 관광사업 개발}

정부는 빈곤경감 정책 추진에 관광사업 확 대' 가 하나의 대안이 될 수 있다고 보고 관광사업 증진을 위한 여러 가지 노력을 기울이고 있다. 1992년 제정된 '국가 관광정책' 을 개정하기 위한 절차가 진행 중이며 방글라데시내 관광 활성화를 위하여 ‘지역 관광개발 위원회' (District Tourism Development Committee)가 설립되었고, '방글 라데시 관광 비전 $2020^{\prime}$ 도 제정되었다.

정부는 주요 관광지역에 '관광정보센터' 를 설립 하여 운영하고 있으며 관광 홍보물 및 포스터 등을 제작하여 외국 공관과 해외 항공사, 각 나라의 방 글라데시 대사관에 배포하였고, 외국 신문사와 잡 지사에 광고물도 게재하고 있다. 2002년부터는 2 년짜리 디플로마 과정으로 '호텔 경영학과'를 신 설하여 관광전문가를 육성하고 있으며, 콕스바잘 (Cox's Bazaar: 방글라데시 남부 해안지역)에 정 부소유 토지를 민간기업에게 양도하여 호텔과 모 텔 건설을 장려하였다.

- 회계년도 2005 '07을 위한 PRSP에는 특정 지역 관광개발 타당성조사 및 마스터 플랜 수립 등을 목표로 설정

- 또한, 자국 관광지 홍보 및 관광 정보수집을 위하여 '세계 관광기구' 가입 및 '관광위성 계정' (Tourism Satellite Account)에 참여를 추진할 예정

- 관광분야 개발을 위한 정보통신 기술 도입, 관광상품 개발, 관광시장 촉진을 위한 기금 확보도 추진예정
- 국가운영 호텔 및 관광훈련원(National Hotel and Tourism Training Institute)의 훈련설비를 향상시키고, 대규모 국제회의 및 전시가 가능한 전시장을 구축하는 등 목표를 가지고 있음.

\section{1. 정보통신 및 생명공학 지원}

\section{가. 정보통신 및 생명공학 개발}

정부는 정보통신 분야와 생명공학 분야의 발전 을 위해 ‘국가 과학 - 기술 정책' (National Policy on Science and Technology) 및 '국가 정보통신 정책' (National Policy on ICT)을 제정하였으며, '국가 과학 기술협회' (National Council for Science and Technology)와 국가 생명공학 상임 위원회' (National Executive committee on Biotechnology)가 설치되었다. 한편 분야별로는 농작 물 생명공학, 동물.수산물 공학, 의료 공학, 안전공 학, 생물다양성 등 5 개 분야의 '기술위원회' 가 설 립되어 운영되고 있다.

정보통신분야 발전을 위한 정책적 지원으로는 정보통신 관련제품에 대한 VAT 철폐 및 세금 면 제, 정보통신 기금 설치 및 지원, 정보통신 인큐베 이터 센터 설립 등이 이루어졌다. 또한 '정보통신 사업 진흥협회' 가 설립되어 방글라데시 IT 사업진 흥에 기여하였고, 해저 광케이블 연결로 인터넷 속 도 향상을 이루고자 하였다.

- 회계년도 2005 '07을 위한 PRSP에는 '국 가 과학 - 기술 정책’ 및 ‘국가 정보 통신 정 
책' 개정, '생명공학 정책' 의 기본틀 마련을 목표로 하고 있음.

- 과학 - 정보통신부내 생명공학부(Biotechnology Cell), 정보통신부, 지적재산권 부가 신설될 예정.

- 농작물 생명공학, 동물 - 수산물 공학, 의료 공학, 안전공학, 생물 다양성 등 5 개분야에 대 한 실행전략과 세부 활동계획이 수립 예정임.

\section{나. 정보통신 및 생명공학 분야 인재육성}

정부는 정보통신 및 생명공학 분야의 인재육성 을 위해 학교와 대학내 정보통신 담당 교사를 양성 하는 프로그램을 도입하였고, 몇몇 대학 내에 정보 통신학과가 개설되었다. 방글라데시내에 6 개의 IT 훈련기관이 설립되었으며, '국가정보통신 자격시 험' (National ICT Certification Examination)과 제도를 도입하여 정보통신 분야의 활성화를 지원 하고 있다.

정보통신 전공 졸업자들을 위한 인턴쉽 프로그 램이 소개되었고, '국가 생명공학기관' 이 설립되 었다. 일부에서는 $\mathrm{E}$-비즈니스 활동이 시도되고 있으며, 정보통신 서비스 확대 및 현대화를 위한 프로그램이 시행중에 있다.

정부는 모든 공공기관 내에서 정보통신 기술이 점차적으로 활용될 수 있도록 정책적으로 지원하고 있다. 투자청과 같은 정부기관에서는 온라인 파일 추적시스템 (file tracking system)을 구축하였고, 몇몇 정부부처는 쌍방향 홈페이지를 오픈하여 선보 였다. 주요 정부부처는 LAN선을 통해 기획위원회
와 총리사무국이 연계되도록 하였다. 정부는 '정보 통신 사업진흥협회' (ICT Business Promotion Council)를 설립하였고, 2002년 11월부터 다카시 내 중심부에 '정보통신 인큐베이터 센터' 를 설립하 여 무료로 인터넷을 사용할 수 있도록 하였으며, 인 터넷 대여 보조금을 제공하여 인터넷 보급에도 힘 쓰고 있다.

- 회계년도 2005 '07을 위한 PRSP에는 IT 훈련센터를 15 개로 확대설립하고 중.고등학 교에 IT교육을 교과과정으로 추가할 계획임.

- 방글라데시-한국 IT훈련센터(BKIICT)가 설 립되어 정보통신 분야의 전문 인력을 양성할 예정이며, 정보통신 인프라 설계를 위한 로 드 맵이 제시되고 전국 모든 중등학교에 컴 퓨터 교육과정이 도입되도록 할 예정임.

한편, 정보통신 기술을 지역적으로 확산시키려 는 노력의 일환으로 방글라데시 전화국은 전화국가입자간 회선을 무선으로 연결하는 무선가입자 회선(Wireless Local Loop) 기술을 사용하여 농촌 및 원거리 지역주민들도 낮은 비용으로 전화를 사 용할 수 있도록 할 예정이며, 인터넷 카페, 인터넷 의료원 등이 지방지역에 설립되어 지방에서의 정 보화 확산에 기여하게 될 것이다. 또한 각 부처가 LAN 선을 통해 연결될 것이다.

전략 3. 효과적인 사회안전 대책프로그램

12. 빈곤경감을 위한 재해 관리 및 안전 대책 


\section{가. 빈곤경감을 위한 안전대책 마련}

빈곤층을 위한 공적구제 제도의 기본 틀이 마 련되었다. 노후보험의 적용 대상을 확대하여 수혜 층이 넓어졌으며, 보조금 수준 또한 향상되었다.

- 회계년도 2005 ’ 07을 위한 PRSP에는 다 른 나라의 공적 구제제도를 점검, 비용효과 가 큰 프로그램의 확대 및 운영 내실화를 추 진 예정.

\section{나. 재해 관리}

홍수 등 빈곤층을 대상으로 재해관리를 위하여 정부는 '포괄적 재해관리 프로그램' (CDMP)을 제 정하고 기상재해 및 예측 불가능한 재해를 효과적 으로 관리하고자 노력하였다. '재해 영향평가' (Disaster Impact and Risk Assessment: DIRA) 를 통하여 피해 예방조치들이 이루어졌으며 외국 원조기관의 도움으로 긴급 피난지역 등이 설치되 었다.

정부는 늘어나는 재해의 효과적 예방 및 긴급구 호를 위하여 ‘재해 관리법' 을 제정하였으며, 부처 간 재해관련 협조계획을 담은 2005 09년 재해관 리부처 협력계획' 수립 및 부처간 협의체인 재난 관리위원회가 설치되었다.

- 회계년도 2005 '07을 위한 PRSP에는 재 해관리 부처를 재해관리부 뿐 아니라, 국가 경제부 및 재무부 등 국가정책 주요부처로 확대하고 재해 및 기상 변화, 위기관리와 같 은 재해대책 프로그램의 공동 대응을 추진 예정임.
- 이를 위한 국가적 재해위기 감소를 위한 관 련 기관간 연계 및 협력 증진, 사회적 지지 프로그램의 개발을 목표로 하고 있음.

- 선(先)경보 제도, 재해 대비, 기후 변화에 따 른 위기 감소 및 재해후 활동의 확대를 위한 기술개발과 인력양성을 목표로 하고 있으며, '재난 구제 기금' (Calamity Relief Block Fund)을 설치함.

\section{다. 정부 기능 강화}

정부는 재해 관리분야에서의 정부기능 강화를 목표로 모든 '재난관리위 원회' 의 규정과 책임을 재검토하였고, ‘훈련수요 평가' (Training Need Assessment)를 시행하였다.

- 회계년도 2005 '07을 위한 PRSP에는 모든 수준에서 '재난관리 위원회' 의 수용력을 향 상시키고, 지역적, 국가적 협력 메커니즘 강 화, 재난 정보공유를 위한 인터넷 네트워킹 설계 등을 목표로 삼고 있음.

\section{전략4. 인적자원 개발}

(Human Resources Development)

\section{3. 교육 분야}

\section{가. 영 - 유아 교육}

인간개발을 목표로 방글라데시 안에서도 유아 유치부와 같은 초등교육 이전의 교육활동의 중요 
성이 이슈화 되었다. 정부는 초등교육 이전 교육의 활성화를 위해 유아·유치부의 커리큘럼 작성을 위한 연구를 시작하였고, 다방면에 걸친 유아교육 프로그램들이 개발되었다. 국내 비정부기관(NGO) 은 물론 국제 NGOs의 지원하에 지역별로 유아 보 육센터가 설립되어 운영 중에 있다. 현재 아동권리 신장과 증진을 위한 '국가 행동계획(NPA)' 이 준비 중에 있으며, NPA내, 유아·유치교육 프로그램 도입과 증진을 목표로 한 제안서가 정부의 승인을 기다리고 있는 중이다.

- 회계년도 2005 '07을 위한 PRSP에는 유아 교육 및 초등 교육 프로그램의 다양화, 교육 의 질 향상을 목표로 여러 가지 세부 실행계 획을 제시함.

- 도시 및 농촌지역의 빈곤가족에게 출생부터 단계적으로 보육을 지원하는 무료 보육프로 그램을 제공함

- 유치원을 초등학교와 붙여서 운영하는 병설 유치원 제도를 도입할 예정이며, 지역학교가 $\mathrm{NGO}$ 와 지역기관에 의해 운영되도록 하는 정책을 수용할 예정임.

- 영 - 유아 학습센터 확대, 유치원 교사의 자 격증제 도입 예정임.

\section{나. 초등교육 분야}

\section{- 초등교육 분야 PRSP}

초등학교 입학율 $100 \%$ 달성과 통합교육 시스템 운영을 위한 국가 경제협의회 2003(National Economic Council)' 의 교육부문 제안사항의
시행이 검토 중에 있다. 초등교육 성취율 향상 을 목표로 출석률 향상, 초등교육 이수율 향상 (현재의 $68 \%$ 에서 $80 \%$ 로) 등이 추진중이며, 중 퇴비율 감소 및 중퇴자들의 재입학률 향상 등을 목표로 하고 있다.

\section{- 빈곤층을 위한 교육 계획}

정부는 35 만에 이르는 도시지역 아동 근로자들 에게 기본교육을 제공할 계획이며 학교에 다니 지 않던 50만명의 아동들을 포함하는 'Reach Out of School children' 프로젝트가 시행되었 다. '초등교육 개발 프로그램II' (PEDP II)에서 는 비교육적 환경에서 교육기회를 갖지 못한 소외계층을 위한 혁신적 보조금 지원정책이 실 행되었다.

한편, 빈곤계층 자녀의 학업장려를 위해 정부 는 빈곤아동의 입학 및 출석에 따라 현금으로 보상하는 'Cash for Education' 제도를 도입하 였으며 정부는 1993년이후 빈곤층 자녀에게 교 과서와 음식을 제공하는 인센티브 제도를 시행 중이다. 음식제공 프로그램은 후에 현금 인센 티브제로 대체되어 한 가정에 한 학생을 보낼 경우 현지화 100 다카 지원, 두명 이상 현지화 125 다카를 지원한다.

- 회계년도 2005 '07을 위한 PRSP에는 초 등학교 학습 커리큘럼에 방글라 언어능력 개발, 수 개념 개발, 기초 생활능력 개발이 포함되도록 구성하여 유아.초등 교육의 질 을 향상하도록 목표를 설정함.

- 한편, 모든 학교에서 남녀, 장애인-비장애 
인, 소수민족 등이 차별 없이 교육을 받을 수 있도록 장려하고 민주주의적 커리큘럼을 개 발 예정임.

- 빈곤계층의 학업중퇴율을 최소화하기 위한 다양한 인센티브 제도를 연구하고 교육의 질 향상을 위한 현대화 프로그램을 지원 예 정임.

\section{다. 중등교육}

정부는 입학률 증가 목표치로 초 · 중학교 입학 률을 $60 \%$ 에서 $90 \%$ 로, 중학교 입학률은 현재의 $44 \%$ 에서 $66 \%$, 고등학교 $17 \%$ 에서 $25 \%$ 로 증가하 는 세부 목표치를 설정하여 시행중에 있다. 또한 마드라사(무슬림 종교학교) 및 일반학교 중퇴비율 을 $50 \%$ 축소하는 것을 목표로 하였다. 그 외 중.고 등교육 이수 자격시험인 SSC와 HSC(Higher Secondary School Certificate)의 합격율을 2008 년까지 최소 $65 \%$ 로 증가시키고 여성의 교육참여 율 증가, 빈곤층 중등 교육 중퇴율 $50 \%$ 절감 등을 목표로 삼고 있다.

- 회계년도 2005 '07을 위한 PRSP에는 소외 계층까지 교육의 혜택을 받을 수 있도록 농 촌지역까지 교육을 확대할 예정임.

- 교육예산 확대를 위한 노력도 지속될 예정이 며, 교사훈련 및 활동실적에 따른 임금제 도 입, 학생성과 평가제도 개선 등을 목표로 추 가함.

- 모든 중학교에 안전식수 제공 및 위생기기 설비 추진
- 또한 출석 여학생에게 지급되는 교육 보조금 혜택이 도지지역 빈곤가정과 빈곤가정의 남 학생에게도 주어지도록 보조금 제도가 확대 할 예정임.

- 아울러, 여학생대상 장학금제도 확대, 여학 생 기숙사 제공, 여학생 교통비 지급 등 여학 생의 중등교육 참여를 프로그램들이 도입

\section{라. 기술 - 직업 훈련}

'기술 - 직업 교육' 프로그램은 8학년 이상 교 육을 이수한 학생들에게 1년에서 4년까지 기술 및 직업관련 교육을 제공받을 수 있도록 구성되어 있 다. 자격증 코스는 163 개 기관과 2,514 비정부기 관(NGOs)에서 제공되고 있다. 자료에 따르면 2003 년 약 28,000 명의 학생들이 등록하여 직업교 육을 받고 있는 것으로 나타났다. 정부는 빈곤경감 프로그램에 직업훈련 과정의 필요성을 인정하고 직업훈련학교 입학률 $50 \%$ 확대, 여성의 직업기술 교육 참여율 $60 \%$ 확대, 각종 기술자격증 취득률 $80 \%$ 확대 등을 목표로 설정하였다.

정부는 노동부산하 직업훈련센터의 2 부제 운영 을 결정하였고, 여성의 직업기술 교육참여율 확대 를 위해 직업교육을 받는 여성에게 특별 보조금을 지원하는 프로그램을 시행하였다. 또한 여성전용 3 개의 기술교육기관을 설립하여 운영중이며, 졸업 생들의 구직확보를 돕기 위해 각 NGOs와 연계하 여 직업 수요조사를 진행하고 있다.

- 회계년도 2005 '07을 위한 PRSP에는 기 업, NGOs와 협력, 여성포함 소외 계층을 위 
한 자영업 기술, 소득창출을 위한 기술교육 과정을 개설할 예정임.

- 민간부문에서의 직업훈련 교육을 적극 지원 예정이며 현행 직업기술 교육 커리큘럼을 재 검토하고, 여성 직업기술교육 이수 학생에게 보조금을 지원하는 프로그램을 도입 예정

- 직업훈련원 교사에 대한 교수법이 정기적으 로 모니터링 될 것이며 교사들을 대상으로 한 훈련강화를 통해 직업훈련 교육의 질 향 상을 추진함.

\section{마. 고등교육 분야}

2005 년 현재 방글라데시는 26 개의 공립 대학 교와 54 개의 사립대학 그리고 1,500 개의 전문대 학(college)이 있는 것으로 조사되었다. 정부는 고 등교육 분야에서의 전문학위 입학율을 현행대비 $40 \%$ 확대하고, 자연계열 전공자 확대, 전문 분야 에서의 남.녀 입학율 $50 \%$ 증가, 석사학위 취득율 $50 \%$ 향상 등을 목표로 설정하였다. 또 국립대학 교육의 질 향상을 위해 연구기기 설비 확충 등 인 프라향상 프로그램을 시행하였고, 교수법 지원, 경 영 및 자연계열 지원 제안을 수용하였다. 한편 연 구비 지원을 위한 예산확대 방안들이 논의되었고 모든 고등교육기관에 적용될 교육의 질 평가기준 이 제시되었다.

- 회계년도 2005 '07을 위한 PRSP에는 고등 교육에 대한지원 확대, 교육분야 장기비전 제시, 시장의 요구에 부응하는 학위과정 개 발, 고등교육 분야의 교육과정 및 시험과 학
생평가제도 재검토 등을 목표로 설정함.

- 1973년에 제정된 '대학운영법' 을 수정하여 대학교의 활동영역과 책임성을 강화하고 정 치적 영향력을 최소화 할 예정

- 대학내에 '대학기부금위원회' 를 독립적인 기관으로 설치하고 동위원회가 교육의 질 향상, 교육평등 구현을 위해 기능하도록 감 독함.

\section{바. 비공식 교육 지원}

정부는 문맹율을 현재의 $63 \%$ 에서 $60 \%$ 로 개선 할 것을 목표로 공교육 뿐아니라 비공식 교육부문 에 대한 지원을 강화할 예정이며, 동시에 2003년 비효율적이고 부작용을 양산한 문자해독률 증가 캠페인을 중단시켰다. 정부는 교육부 산하 교육기 관을 통해 3 백만명의 문맹자를 대상으로 문자교육 을 실시하는 내용의 교육프로젝트를 설계하여 운 영중에 있다.

- 회계년도 2005 '07을 위한 PRSP에는 비공 식부문 교육지원을 위해 NGOs 와 지역사회 간 파트너쉽 확대, 기술적 지원 제공, 운영자 금 지원강화 등을 추진예정.

- 그외에도 평생교육제도 개발 정책을 위한 비 전도 제시함.

\section{사. 교육제도와 교육 재정}

정부는 장기적 교육환경 개선을 목표로, 2007년 까지 소외지역에 50\%이상 학교 증설, 2007년까 지 교육비 및 학교보조금 누락율 $75 \%$ 축소, 
2007년까지 모든 교사의 교원자격증 확보를 목 표로 여러 가지 교육관련 프로그램을 시행하고 있다. 또한 정부는 '통합재정관리 개혁프로그램' 아래 교육분야발전을 위한 ‘중기지출 프로그램' (Medium Term Expenditure Framework: $\mathrm{MTEF}$ )를 제정하여 시행중에 있다. 2003년 '국 가 경제협의회' 보고서는 교육분야에서 지방분 권(decentralization)의 중요성에 대해 언급하고 있다.

- 회계년도 2005 '07을 위한 PRSP에는 교육 프로그램과 프로젝트가 빈곤경감에 미치는 영향을 분석하고, 교육예산 및 감사 제도를 평가할 것을 목표로 하고 있음.

- 또한 학교운영 효율성을 저해하고 있는 학 교 관리위원회' 의 개혁과 국정교과서 인쇄회 사의 민영화, 교육기관의 책임성과 투명성 강화를 목표로 하고 있음.

- 교육예산은 현재 정부예산의 $13.4 \%$ 수준에 서 2004-2010년간 25\%로 확대시키고 GNP 의 $5 \%$ 로 확대편성을 목표로 함.

- 한편, 빈곤계층 학생을 위한 보조금 지원 프 로그램들을 점검하고, 여학생 보조금 지원정 책 관리 강화, 각 수준별 교사들의 활동실적 에 따른 임금 결정제도가 정착되도록 함.

- 아울러 교사에 대한 교육훈련 강화, 교사 최 소 자질기준 설정을 통해 교육의 질 향상 및 교육 활성화를 실현코자 함.

\section{4. 보건위생 분야}

\section{가. 여성과 아동 보건 향상}

정부는 2003년 여성과 아동의 보건 향상을 위 해 아래와 같은 다분야에서의 보건행상 목표를 설 정하여 실현하고자 하였다. 이들 중 일부는 실현되 었으나 대부분은 PRSP를 통해 2007년까지 해결 을 요하는 것이다.

- 신생아 사망률 2004 년의 1,000 명당 41 명에 서 2006년 32명으로 감소

- 유아 사망률 2004 년의 1,000 명당 88 명에서 2006년 47.9명으로 감소

- 산모 사망률 2001년의 100,000명당 320명 에서 2006년 275명으로 감소

-5 세미만 여아사망률 2000 년 의 1,000 명당 107명, 2006년 102명으로 감소

- 아동 사고사망률 1997 년의 $1.86 \%$ 에서 2006 년 $1.1 \%$ 로 감소

- 농촌지역아동 사망률 2000 년의 1,000 명당 140명, 2006년 120명으로 감소

- 여성 평균수명 2002년의 65세에서 2006년 70세로 연장

- 여성 질병사망률 2002 년의 1,000 명당 4.8 명 에서 2006년 4.4명으로 감소

- 산전진찰률 2004 년의 $48.7 \%$ 에서 2006 년 $60 \%$ 로 증가

- 산후 진찰률 2004 년의 $17.8 \%$ 에서 2006 년 $30 \%$ 로 증가

- 필수 분만간호 서비스 이용률 2003년의 $26.5 \%$ 에서 2006 년 $40 \%$ 로 증가

- 모든 필요여성에게 응급분만서비스 제공 
- 전문의료진도움을 받는 출산률 2004년의 13.4\%에서 2006년 25\%로 증가

- 피임보급률 2004년의 58.1\%에서 2006년 $63 \%$ 로 증가(남성의 피임도구 사용율 확대)

- 합계출산율(TFR) 2004년의 3.0명에서 2006년 2.8명으로 감소

정부는 보건분야 필수 서비스를 제공하고 있으 며, 예방접종 프로그램 확대, 급성 호흡성간염 (ARI) 통제, 설사병 통제, 통합 아동질병 관리 (IMCI), 학교 보건서비스 개선 등 아동을 위한 보 건서비스의 질을 향상시켰으며, 보건분야 재정 확 보를 위한 노력을 기울여 왔다.

국가적 차원에서 ‘의약품 정책', “보건 정책’ 을 시행하였으며, 모든 산모에게 파상풍 예방접종 (TT)을 포함한 산전검진 서비스 제공과, 응급분만 서비스 제공, 위탁서비스 제공 등 여성을 위한 보 건정책을 펼쳤다. 아울러 '인구조절정책' 시행, '산모보건' 전략 제시 및 응급 피임법 개발에 힘썼 으며, 여성 매춘업 종사자들을 위한 HIV/AIDS 프 로그램을 실시하였고, 여성을 위한 2개의 '원스탑 응급센터' (One-stop Crisis Center)를 설립하여 운영하고 있다.

- 회계년도 2005 '07을 PRSP에는 여성.아동 보건 프로그램 강화, 필수 분만 서비스 강화, 예방접종 프로그램 확대 및 유지, 통합아동 질병관리' 강화, 법적 결혼 허용 나이 시행 강화, 신생아 등록 강화, 전문의료진의 도움 을 받는 출산율 강화, 남성의 적극적 피임사 용 장려 등을 목표 함.
- 또한 장기적으로 여성 친화적 일자리 제공, 여성의 보건·의료관련 지식 증진, 여성과 아동의 보건 · 의료 관련 보조금 제공, 의 사·간호사 등 의료진 전문화 훈련, 여성대 상 보건서비스 확대 등을 목표로 함.

\section{나. 청소년 보건 증진}

정부는 청소년 산모비율 감소, 모든 청소년에 게 출산관련 보건지식 교육, 청소년 HIV/AIDS 감 염 통로 근절, 청소년 성적 학대방지, 알코올, 마약 에서 자유로운 환경 제공 등을 목표로 학교내 보건 프로그램을 실시하여 왔다. 특히 청소년 여성폭력 피해자를 위한 센터를 건립하여 운영하였으며 HIV/AIDS 근절 프로그램을 시작하였다.

- 회계년도 2005 '07을 위한 PRSP에는 청소 년 보건 증진을 목표로 청소년 보건센터 건 립, 청소년에게 ‘필수 보건서비스' 제공, 청 소년 마약 중독자를 위한 재활 프로그램 설 계를 목표로 함.

\section{다. 전염성, 비전염성 질병 통제}

정부는 방글라데시 질병통제의 일환으로 결핵 양성사례 발견률을 2002년 34\%에서 2006년 65\% 로 확대하고, 2000 년 10,000 명당 0.63 명의 나환 자 발병률(leprosy prevalence rate)을 2006년까 지 0.50 명으로 축소, 말라리아 사망률은 2003년 595명에서 2006/7년까지 20\% 축소, HIV/AIDS 확산 관리(발병위험 인구 $5 \%$ 이내), 심장병, 암, 당 뇨, 상해, 사고 등 비전염성 질병률 및 사망률 감 
소, 담배 및 알코올 소비량 통제 등을 목표로 정부 는 국가적 차원에서 결핵통제 프로그램과 단기 DOTS(직접관찰치료) 프로그램을 시행하였다.

또한 말라리아 조기 검진 및 조기 치료를 위해 노력하였으며 나환자 통제 프로그램, B형간염 예 방 접종 프로그램, 식당 등 공공장소의 위생관리 점검 프로그램 등을 시행하여 효과적인 질병통제 를 위해 노력하였다.

- 회계년도 2005 '07을 위한 PRSP에는 혈액 안전 프로그램 확대 및 강화, 행동변화 프로 그램 $(\mathrm{BBC})$ 확대 및 강화, 질병감시 프로그램 강화, 알코올 및 담배소비 확산통제, 당뇨 병 · 암 - 심장병 등 비전염성 질병 조기진단 및 조기치료 확산 등을 목표로 하고 있음.

\section{라. 산모 · 아동 영양 개선}

정부는 산모와 아동의 영양상태 향상을 위해 아래와 같은 목표를 설정하였다.

- 주요 2 가지 단백질 결핍으로 인한 영양실조 율(U2PEM) 1995년 12.6\%에서 2006년 5\% 미만으로 감소

- 극저체중아 출생율 1995년 50\%에서 2006년 $15 \%$ 로 감소

- 발육 부전률 1995년 62\%에서 2006년 35\% 로 감소

- 신체 질량지수 1995년 60\%에서 2006년 $40 \%$ 로 감소

- 5세미만 여아 저체중률 1990년 8\%에서 2006년 0\%로 감소
- 5세미만 여아 극저체중률 1990년 26\%에서 2006년 10\%로 감소

- 1 5세 아동 야맹증 2003년 0.6\%에서 2006 년 $6.2 \%$ 로 감소

- 빈곤층 내 아동영양실조율 감소

- 산모 빈혈증세 현재의 70\%에서 2006년 $45 \%$ 로 감소

- 청소년 산모 빈혈증세 현재의 $65 \%$ 에서 2006년 25\%로 감소

- 요오드 결핍증세 2003년 69\%에서 2006년 $25 \%$ 로 감소

정부는 영양프로그램을 실시하였고, 미량영양 소 보충 프로그램을 실시하였다. 저체중 아동 탄생 률 감소를 위한 특별보호 프로그램을 실시하였으 며, 향상된 영양 섭취를 위한 행동변화 프로그램, 산모수유제도 확산, 미량 영양소함유 음식섭취, 지 역사회내 영양프로그램 개발, 요오드 결핍증세 통 제 등 여러가지 프로그램을 시행하였다.

- 회계년도 2005 '07을 위한 PRSP에는 영양 제도 및 영양 프로그램 농촌지역으로 확산, 도시지역내 필수영양 수요조사 실시, 지역 영양소를 현재의 20 개 지역에서 64 개 지역 으로 확대, 학교내 급식프로그램 도입 등을 목표로 설정함.

\section{마. 안전식수 설비}

정부는 안전식수 비 수혜층을 2006년까지 전 가구의 $26 \%$ 에서 $14 \%$ 로 축소시키고, 위생지표 비 도달 계층도 2006 년까지 $66 \%$ 에서 $33 \%$ 로 절감하 
기로 목표를 세웠으며, 2010 년까지 $100 \%$ 위생 도 달률을 목표로 여러가지 방안을 내 놓았다. 그 외 에도 오염된 식수로 인한 질병과 사망율을 경감하 고, 비소함유 식수 섭취인구의 감소, 공공장소내 화장실 위생확보를 목표로 상수도에 비소 (arsenic)함유 측정기를 도입하였고, 1998년에는 ‘위생개선을 위한 국가정책' 을 실시하였다. 2004 년에는 비소중독 예방대책을 수립하여 시행하였 고, 비소함유 식수섭취 희생자들을 위한 '의료 서비스 를 시작하였다.

- 회계년도 2005 '07을 위한 PRSP에는 새천 년 개발목표(MDGs) 달성을 위한 식수, 위생 개선 정책수립, 위생 프로젝트와 상수도를 모든 도시 지역에 확대 설치, 수자원관련 문 제 최소화를 위한 안전식수 공급 프로그램 운영, 식수의 질 점검 프로그램 운영을 주요 목표로 설정함.

- 또한 일반인의 위생습관 개선을 위한 행동변 화 캠페인 전개와 저렴한 비용의 안전식수 공급과 위생환경 개선을 위한 연구가 진행될 예정임.

\section{바. 전반적 보건 지수 향상}

정부는 평균수명을 2000년 61세에서 2007년 66세로 증가시키고 인구성장률을 2000년 $1.6 \%$ 에 서 2007년 1.5\%로 감소하는 것을 목표로 하였다. 또한 보건 서비스 개선 및 보건분야 예산확대 필요 성이 대두되었으며, 2003-06년간 4년간 보건,영 양, 인구 프로그램을 수행하였다.
- 회계년도 2005 '07을 위한 PRSP에는 보건 서비스 개혁 모니터링 , '보건·영양-인구 협의회' 설립, 빈곤지역 정기적 확인, 지역의 료 보험제도 개선을 위한 조사 실시, 지역보 건소 관리 등을 목표로 설정함.

보조전략. 비주류의 사회참여 및 좋은 통치 (Good Governance)

\section{6. 여성권리 및 여성 참여 확대}

\section{가. 경제에서의 여성참여 확대}

1) 일자리에서 여성 차별 현황

방글라데시내 여성의 고용인원은 남성 고용인 원과 비교해 볼 때 매우 저조한 편이며, 임금수준 도 낮은 편이다. 2000년 보고서에 따르면, 전체 노 동인력중 무급 노동자는 남성이 $6.4 \%$ 인데 비해 여 성은 $34.3 \%$ 로 나타났다. $\mathrm{EH}$ 한 자영업 종사비율 을 보면 남성이 $51.6 \%$ 인데 비해 여성은 $21.6 \%$ 만 이 자영업(self-employed)에 종사하는 것으로 나 타났다.

평균적으로 방글라데시 여성의 임금은 남성 노 동자의 $58.5 \%$ 밖에 되지 않는 것으로 나타났다. 더욱이 자영업 종사여성의 $66 \%$ 는 한달에 1,000 다 카 $(\$ 15)$ 미만의 수입을 올리는 것으로 나타났으며, 이에 반하여 자영업 남성 종사자들의 $92.7 \%$ 는 한 달에 현지화 1,000 다카 이상의 수입을 올리는 것 으로 집계되었다. 봉급자들의 경우 $61 \%$ 의 근로 여 
성들이 매달 현지화 1,000 다카 미만의 임금을 받 고 있고 있는 반면 남성 근로자의 $84 \%$ 는 매달 1,000 다카 이상의 임금을 받는 것으로 나타났다. 남.녀 실업율은 여성 $7.8 \%$, 남성 $3.4 \%$ 로 나타났으 며 불완전고용율(underemployment)도 여성이 $52.8 \%$, 남성 $7.4 \%$ 로 나타나는 등 남 - 녀의 격차 가 심각한 수준임을 알 수 있다.

\section{2) 여성차별 제거}

정부는 여성의 경제활동을 장려하고 모든 여성 차별 장벽을 제거함과 함께 전문직 여성노동자가 고임금 받을 수 있도록 환경을 조성하고, 효과적 예산집행으로 여성의 직업훈련 및 IT훈련을 지원 하고 있다. 또한 고용기회 및 고용 절차에서 남녀 차별을 줄이고 평등한 근로환경과 임금제도 확산 을 위해 고용인과 고용주간 노동법 상호이해 증진 을 위한 노력을 지속적으로 해오고 있다.

\section{3) 여성의 경제적 활동 참여 장려}

정부는 2015 년까지 빈곤 여성을 $50 \%$ 감소하는 것을 목표로 여성을 위한 다양한 프로그램과 정책 을 실시하였다. 여성 친환경적 일자리 조성을 위해 사내에 '아동 탁아시설' 을 설립하고, 4 개월-여성 출산휴가제를 정부 및 공공기관에서 먼저 시행하 고 있다. 농촌 여성들의 일자리 창출 프로젝트가 시작되었으며, 여성 기업인을 위한 소액대출 지원 제도 및 빈곤여성을 위한 '취약계층 개발' 프로그 램을 시행하였다.

- 회계년도 2005 '07을 위한 PRSP에는 여성
의 공정한 취업기회 제공 및 남녀평등 임금 정책 실시, 물가상승율에 따른 임금 책정제 도 강화를 주 목표로 하고 있음.

\section{나. 여성 폭력 근절}

여성폭력 사건이 $100 \%$ 파악되도록 추적하고 있 으며 여성폭력 발생율을 $50 \%$ 축소할 것을 목표로 정부는 여성 납치, 성매매 관련 사회홍보 및 경찰 인지도 확산 프로그램을 시행하였고 여성간 네트 워킹 구축, 강간피해 여성들을 위한 PEP test 지 원, 성폭력 피해자를 위한 ‘원스탑 위기센터' 운영, 성매춘 여성 종사자들을 위한 재활센터설립 등 다 양한 여성폭력 근절을 위한 시도가 있었다.

- 회계년도 2005 '07을 위한 PRSP에는 2003년 제정 ‘여성 및 아동 폭력 금지법’ 에 가정내 폭력도 범죄로 추가 포함할 예정이 며, 피해여성들을 위한 지원 확대, 여성폭력 예방캠페인, 여성폭력 담당 경찰관과 의료경 찰 훈련 제공을 목표로 하고 있음.

- 그 외에도 여성의 권리 신장을 위해 여성권 리 관련 소송에는 '여성차별철폐위원회' 규 정에 입각한 법적판결을 내리도록 홍보할 예 정임.

\section{7. 좋은 통치(Good Governance)}

\section{가. 의미와 범위}

좋은 통치(Good Governance)의 광범위한 의 미는 국가기관의 권위와 정당성, 법 규범에 따른 
권력행사, 국가 공무원의 권한과 책임, 정책 결정 에 있어서의 정부의 권한, 행정 관리, 회계 관계, 공공서비스 제공 등을 포함하고 있다. 좋은 통치와 관련한 효과적인 전략 설정을 위해서는 4가지 취 약점을 타파해야 한다. 즉 i) 어젠다 선정시 백과사 전식 희망사항 리스트만 만드는 경향 ii) 개혁에 대 한 공무원의 이해 부족 및 반발, iii) 진행되지 않는 현안에 관심을 더 깊은 가지는 한편, 진행되고 있 는 현안에 무관심한 점, iv) 명확성 부족.

\section{나. 우선순위 선정}

다음 5 가지는 거버넌스관련 이슈의 주요 우선 순위로 거론되는 것이다. i) 실천역량 강화, ii) 지 방정부 능력향상, iii) 반부패 전략 강화, iv) 빈곤층 의 사법제도 이용확대 및 형법 개혁, iv) 분야별 체 제 향상

\section{다. 전략 설정}

방글라데시 내에서 공공 서비스의 질은 매우 낮은 것으로 나타났으며 이는 성과보상 시스템과 관련이 있다. 예컨대, 정부의 교육예산 분배는 그 들의 활동실적에 따라 결정되어야 한다. 정확하고 효과적인 활동실적 점검을 위해서는 교육기관의 시험합격률을 고려할 수 있다. 최근 설립된 '모범 학교' 프로젝트는 교육의 기본적인 기준을 제시하 고 교육 서비스의 질 향상을 목표로 한 혁신적인 시도라 할 수 있다. 교육, 보건의 질 향상은 사회개 발의 불균형을 최소화 할 수 있으며 빈부격차 및 도-농간 격차를 줄이는데 도움을 준다. 여전히 극
빈층은 여러가지 사회적, 정책적 혜택에서 소외되 고 있다. 빈곤해결을 위한 사회개발 프로그램의 다 양화가 필요한 시점이다.

\section{라. 정부의 활동 및 PRSP 의제}

\section{- 실천역량 강화}

거버넌스 이슈 관련, 정부는 실천역량의 강화 를 위해 2005년 ‘중기예산편성제도' (Medium Term Budgetary Framework)를 도입하였다. 정부는 재원부족(under-funded) 으로 인한 프 로젝트 실패 사례를 제거하기 위해 시범적으로 10 개의 정부부처에 $3 \sim 5$ 년 간 $\mathrm{MTBF}$ 에 기초한 기본 예산안을 편성하여 제출하도록 지시하였 다. '국가 조정위원회' 가 총리실에 설치되어 시 급한 국가적 현안들을 해결하고 있으며, 예산 지출의 투명성을 검토할 ‘지불 위원회’ (Pay Commission)의 년간 사업검토 보고서가 발행 되었다.

- 회계년도 2005 '07을 위한 PRSP에는 '중 기예산 편성제도' 이행을 위한 모니터링을 실시하고, 동 제도를 더 많은 부처에 확산하 는 조치가 시행 예정임.

- 그 외에도 공공부문 우수인력 확보 및 인력 훈련 기관의 위상 강화, 우량 프로젝트의 시 행 등이 있음.

\section{- 지방정부 역량 강화}

정부는 지방정부의 역량강화를 목표로 상당수 의 복합훈련센터를 건립하여 운영하고 있다. 지방정부 공무원에게 각종 훈련을 시행하고 있 
으며 지방정부 행정책임자의 지위를 향상시켜 지방정부의 역량강화를 도모하였다. 또한 지방 정부만을 위한 새로운 세금제도가 승인되었으 며 소규모 행정단위(읍 · 면) 기능 강화를 위한 예비 프로젝트가 시행중에 있다.

한편 정부는 지방정부가 자체 개발사업을 위 하여 연간 개발계획(Annual Development Program: ADP) 예산을 직접 공여받을 수 있 도록 하였다.

- 회계년도 2005 '07을 위한 PRSP에는 지방 정부 공무원 훈련편람이 개정될 예정임.

- 지방정부에 선거제를 도입하고, 지방정부 행 정구조 및 선거주기(cycle)를 재검토하며, 포 괄적인 '지방정부 법안' (Local Government Act)을 제정할 예정.

- 지방개발을 위한 예산지출시 국회의원의 영 향력을 축소시키고 지방정부가 직접 예산을 배정받도록 하는 등 지방정부의 역량을 강화 및 부정소지 예방을 추진함.

- 현재 지방정부에 부여된 세입(현행 $1 \%$ 의 토지 개발세)는 $5 \%$ 로 증가되어야 하며 지방정부가 직접적으로 세입예산을 관리 · 운영하도록 할 것임.

\section{- 반부패 전략}

방글라데시는 국제 NGOs인 Transparency International(TI)의 국가별 부패지수 (corruption perception index) 조사에서 조사 대상 159 개 국가중 최하위를 기록하며 5 년연속 부패지수 1 위인 가장 부패한 나라로 선정되었
다. 본 조사는 방글라데시 내부행정 및 공무원 들의 심각한 부패수준을 그대로 반영해 주는 지표이다. 정부는 부패 근절을 목표로 반부패 위원회 법안' (Anti-Corruption Commission Act)을 통과시켰으며, 3 명의 위원을 선임하여 운영하고 있다. 위원회 설립과 동시에 예전의 반 부패청(Anti-Corruption Bureau)은 해산되었 다. 1992 년 6월 정부는 '공공지출 검토 위원회' (Public Expenditure Review Commission)와 '공공세입제도 개혁 위원회' (Commission Reforming Public Revenue System)를 설립 하였다. 또한 ‘중기예산 편성제도' 의 도입과 함 께 '예산 모니터링 제도', '자원 위원회’, ‘중기 예산조정 및 자본위원회' 가 설치되어 공무원 및 정치인의 공무관련 부정방지를 막기위한 제도 적 방안이 마련되었고 비리자 처벌수위를 대폭 강화하였다.

- 형사사법제도 개혁 및 빈곤층의 사법제도 접근 강화

정부는 사법제도에서의 good governance 달 성을 위하여 형사사법 개혁 및 경찰개혁을 목 표로 다양한 활동들을 전개해 왔다. 정부는 2002년 일반인들의 사법서비스 접근을 용이하 게 하기 위해 '신속 재판법' (Speedy Trial Act) 안을 통과시켰고, 9 개의 이동 법정이 지방에 설 치하였다. 2004년에는 강력범죄 소탕을 위해 기동타격대(Rapid Action Battalion)가 생겼으 며 2002년에는 여성을 주 대상으로 한 염산 테 러처벌법(Acid Offences Act)을 제정하여 시행 
하였다.

현재는 형사사법 강화 및 빈곤층의 사법제도 이용율 강화를 위한 프로젝트가 시행중에 있 다. 경찰력은 05 년 현재 13,000 명으로 증가되 었으며, 경찰 서비스 개선을 위한 위원회가 설 치되어 주요 개선안이 정부에 제출되었다.

- 회계년도 2005 '07을 위한 PRSP에는 사법 권을 권력에서 완전하게 분리하는 것을 목표 로 하고 있음.

- 특수경찰대 등 치안확보를 위한 경찰력 강화 와 동시에 경찰의 비필수적 업무(의전 및 VIP수행 등)는 축소 예정임.

\section{PRSP 평가 및 향후 전망}

\section{1. 향후 경제전망 및 PRSP 추진}

방글라데시 경제는 전술한 바와 같이 수출, 외 환관리면에서의 여러 가지 도전요인에도 불구하 고, 거시경제의 안정과 개인투자 확대, 정부와 선 진 원조기관의 경제개혁 노력이 조화를 이루어 진 행된다면 향후 2-3년간 경제성장율을 5 6\% 이상 의 높은 수준으로 유지할 것으로 전망된다. 유엔은 방글라데시 정부가 규제 완화, 인프라 확충(특히 항만과 에너지부문), 재정건전성 강화, 노동의 질 향상, 무역장벽 완화 등의 조치를 성실히 수행할 경우 경제성장율이 약 7 8\% 까지 확대될 수 있을 것으로 전망하였다.

재정건전성의 강화와 관련하여서는, 저축율 증
대만으로는 투자확대에 한계가 예상되며 국가세입 의 건전성, 투명성 확보 및 징수율 확대, 공여국의 지속적인 지원과 외국 자본유입 증가가 필요할 것 으로 보인다.

한편, 방글라데시 정부가 ’05.11 마련한 빈곤경 감전략 보고서(PRSP)는 개발과 성장을 위한 여러 도전과제와 실행전략을 포함하고 있다. $\mathrm{PRSP}$ 는 정부의 과감한 개혁을 강조하며 야심찬 개발목표 달성을 위한 장기 전략과'05 '07년간의 운용계 획(rolling plan)을 두고 있다. 개발계획의 수립과 집행에 있어 빈곤친화적(pro-poor) 전략을 추진 하며 이는 MDGs의 달성과 연계하여 상호 조화로 운 정책과 실시계획을 제공하고 있는 것으로 평가 된다. '05.11 다카에서 개최된 PRSP 집행회의에 서는 방글라데시 정부가 마련한 개발전략에 대한 공여국들의 동의와 충분한 지원을 약속하는 결의 가 있었다.

\section{2. 전략의 효율성 평가}

정부작성 빈곤경감 전략은 오랜 준비기간을 거 쳐 여러 이해집단(학계, 경제계, $\mathrm{NGO}$, 원조기관 등)간 논의와 과거 개발전략의 공과를 검토 후 작 성되었다. 정부는 전략의 가치를 증진하기 위해 전 략이행 상황을 모니터링하고 평가하기 위한 장치 를 마련하였으며 동 과정에 원조기관, $\mathrm{NGO들의}$ 참여를 환영하고 있다.

다만, 일부 전문가들은 금번의 $\mathrm{PRSP}$ 가 방글라 데시의 현실을 정확하게 반영하여 작성되었는지에 의구심을 표하고 있다. 보건 및 교육분야에서 방글 
라데시가 분명 일정한 성과를 보여주었지만 동 수 준은 여전히 절대치로서 열악한 상태를 면하지 못 하고 있으며, 2000 년 이후의 보건의료, 교육분야 진전율은 정체상태에 머물고 있다. 인구증가율, 초· 중등학교 수료율, 모성사망율 등의 수치는 정 부의 노력과는 다르게 개선조짐이 없는 것으로 보 인다.

무엇보다 PRSP 장래를 어둡게 하는 것은 최근 의 정치현황과 거버넌스 이슈이다. 방글라데시는 2007년 초 총선을 앞두고 있으며 정치권은 이슬람 원리주의자의 과격테러 등 혼란이 가중되고 있다. 정부여당은 $\mathrm{PRSP}$ 의 실효적이행보다는 여당인 $\mathrm{BNP}$ 정권의 치적을 홍보하는데 치중하고 있으며, $\mathrm{PRSP}$ 가 자국의 빈곤 현실을 솔직히 드러내기보다 미래의 불확실한 목표들을 장밋빛으로 치장하였다 는 의구심을 받고 있다.

거버넌스(좋은 통치) 이슈와 관련해서는 전술한 바와 같이 방글라데시가 2000년 이후 거버넌스 상 황이 개선되기 보다 오히려 악화되었다는 점에서 충격적이며, 그것도 거버넌스의 주요 측면 - 부정 부패 관리법에 의한 통치, 정치적 안정에서 조사대 상국 209개국 가운데 지속적으로 최하위를 기록 하여 PRSP 이행 가능성에 대한 어두운 전망을 낳 고 있다.

원조기관들은 정치적 상황속에서 진행된 금번 'PRSP 집행을 위한 국제회의' 에서 방글라데시 정 부가 제시한 목표들과 목표들의 이행을 검증하기 위해 년간 2 회의 집행평가회의를 갖도록 제안하였 으며, 정부는 이에 마지못해 동의하였다.
$\mathrm{PRSP}$ 이행과 관련된 한 가지 긍정적인 요인은 방글라데시 경제전망이 밝은 편이고 민간부문의 성장을 통해 빈곤경감 이슈들도 개선될 것을 기대 하고 있다는 점이다. 원조기관들은 정부의 행정관 리 능력 향상과 함께 민간부문의 영향력을 확대시 키는 쪽으로 원조전략을 마련하여 왔으며 향후 $\mathrm{PRSP}$ 의 전개과정에서 원조기관과 $\mathrm{NGO}$ 등 시민 단체들의 역할이 더욱 중요해질 것이다.

금번 정부가 작성한 $\mathrm{PRSP}$ 는 고정된 것이 아니 며, 경제상황의 변화에 따라 유연하게 수정을 예고 하고 있다는 점에서 정부, 민간, 원조기관 모두의 협력과 도움을 필요로 하고 있다.

\section{MDGs와의 연계}

PRSP는 2000년 유엔총회에서 결의된 밀레니 엄 개발목표(MDGs: Millennium Development Gols) 달성을 위한 방글라데시의 국가개발전략 및 빈곤경감 계획이라 할 수 있다. $\mathrm{PRSP}$ 는 빈곤을 다 음 세대로 이전하지 않고 우리 세대에서 해결하겠 다는 방글라데시 정부의 결의이다. MDGs 달성을 위해 방글라데시의 PRSP는 빈곤경감(특히 기아 퇴치와 구조적 빈곤문제에 집중)과 사회개발(특별 히 여성, 어린이 권익신장)이 상호 독립적이고 유 기적으로 연계되도록 목표를 설정하였다. 방글라 데시가 2015년까지 달성해야할 주요 MDGs 목표 는 다음과 같다.

- 빈곤선 아래에서 생활하는 빈민층 $50 \%$ 감소

- 모든 여· 남아에게 보편적 초등교육 실시

- 초중등 교육 내 여성 차별 철폐 
- 유아 및 5 세미만 아동 사망률 $65 \%$ 감소 및 남녀격차 해소

- 5 세미만 아동 영양실조률 $50 \%$ 감소 및 남녀 격차 해소

- 산모 사망률 $75 \%$ 감소
- 생산적 보건 서비스 확산 및 서비스의 질 개선

- 사회적 폭력, 특히 빈곤층과 여성 및 아동에 게 가해지는 폭력 근절

- 국가 개발계획에 '재해 관리', '환경유지' 과 제들을 포함시킴

\section{〈빈곤경감관련 사회개발 분야 MDGs 〉}

\begin{tabular}{l|c|c|c|c|c}
\hline \multicolumn{1}{|c|}{ 개발 지표 } & 1990년 & 2002년 기준 & $\begin{array}{c}\text { 연평균 개선율 } \\
(1990-02)(\%)\end{array}$ & $\begin{array}{c}\text { 2015 MDGs } \\
\text { 목표 }\end{array}$ & $\begin{array}{c}\text { 연평균개선률 } \\
(2002-15)(\%)\end{array}$ \\
\hline 수입 빈곤층 (\%) & 59 & $* 50$ & -1.5 & 25 & -3.3 \\
절대 빈곤층 (\%) & 28 & $* 19$ & -3.2 & 9.5 & -3.3 \\
성인 문자해독률 (\%) & 35 & 49.6 & 3.5 & 9. & 6.3 \\
초등교육 입 학률 $(\%)$ & 56 & 86.7 & 4.6 & 100 & 1.2 \\
중등교 육 입학률 (\%) & 28 & 52.8 & 7.4 & 95 & 6.1 \\
5세미만 사망률 (천명당) & 108 & 76 & -2.5 & 25 & -5.2 \\
산모 사망률 (십만명당) & 554 & 390 & -2.5 & 98 & -5.8 \\
평균 수명 (세) & 56 & 64.9 & 1.3 & 73 & 1.0 \\
인구 성장률 (\%) & 2.1 & 1.4 &.- & 1.3 &.- \\
아동 저체중률 (\%) & 67 & $* 51$ & -2.4 & 26 & -3.3 \\
\hline
\end{tabular}




\section{[ 참 고 문헌 ]}

- Unlocking the Potential- National Strategy for Accelerated Poverty Reduction, GED, Planning Commission, Ministry of Finance, 2005

- Bangladesh Development Series- Bangladesh PRSP Forum Economic Update, 2005

- Bangladesh Progress Report- Millennium Development Goals, UN/Government of Bangladesh, 2005

- The Structure and distribution of personal income and poverty reduction in Bangladesh, Khan AR, 2004

- 2003 Statistical Year Book, Bangladesh Bureau of Statistics, 2004

- Annual Development Plan, Planning Commission, Ministry of Finance, 2005

- 2005 World Development Indicators, World Bank, 2005

- 방글라데시 원조그룹 home page:

- UNDP home page:

- ADB home page:

- CIDA: www.acdi-cida.gc.ca/CIDAWEB/webcountry.nsf VLUDocEn/factsatsglance 